STATE OF ILLINOIS

Dwight H. Grees, Gozernor

DEPARTMF IT OF REGISTR.ATION A.ND FDLCATION

Fraxk G. Thompsos, Direclor

DIVISION OF THE

NATLRAL HISTORY SLRVEY

THEODORE H. Frison, Chief

Volume 21

\title{
Preliminary Investigation of Oak Diseases in Illinois
}

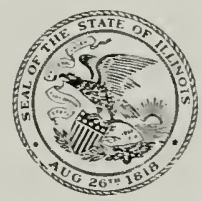


S T A T E OF I L L I NOIS

Dwight H. Green, Governor

\section{DEPARTMENT OF REGISTRATION AND EDUCATION}

Frank G. ThOMPson, Direclor

\section{BOARD OF NATURAL RESOURCES AND CONSERVATION}

Frank G. Thompson, Chairman

William Trelease, D.Sc., Ll.D., Biology William A. Noyes, Ph.D., Ll.D., Chem.D.,

Ezra J. Kraus, Ph.D., D.Sc., Forestry

D.Sc., Chemistry

L. R. Howson, B.S.C.E., C.E., Engineering Edson S. Bastrin, Ph.D., Geology

Arthur Cutts Willard, D.Eng., LL.D.,

President of the University of Illinois

\section{NATURAL HISTORY SURVEY DIVISION Urbana, Illinois}

\section{SCIENTIFIC AND TeChNical STAFF \\ Theodore H. Frison, Ph.D., Chief}

\section{Section of Economic Entomology}

W. P. FLINT, B.S., Chief Entomologist

C. C. Compton, Ph.D., Associate Entomologist

M. D. Farrar, Ph.D., Research Entomologist

J. H. BIGGER, B.S., Associate Entomologist

S. C. CHANDLER, B.S., Southern Field Entomologist

L. H. Shropshire, M.S., Northern Field Entomologist

W. E. McC Auley, M.S., Assistant Entomologist

M. M. Petrakis, B.A., Entomological Assistant

C. J. Weinman, Ph.D., Research Fellow in Entomology

H. B. Petry, B.A., Research Fellow in Entomology

B. G. Berger, M.A., Research Fellow in Entomology

T. F. Winburn, M.S., Associate Entomologist (U.S.B.E.P.Q. and Commodity Credit Corporation, cooperating)

\section{Section of Insect Survey}

H. H. Ross, Ph.D., Systematic Entomologist

Carl O. Mohr, Ph.D., Associate Entomologist, Artist

B. D. Burks, Ph.D., Assistant Entomologist

G. T. Riegel, M.S., Entomological Assistant

Kathryn M. Sommerman, M.S., Artist, Entomological Assistant

\section{Section of Forestry}

James E. Davis, M.F., Extension Forester

LeE E. Yeager, Ph.D., Forester
Section of Aquatic Biology

D. H. Thомpson, Ph.D., Zoologist

George WV. Bennetr, Ph.D., Limnologist

D. F. Hansen, Ph.D., Assistant Zoologist

BrUno Limbach, B.S., Zoological Assistant

Section of Game Researcb and Management Ralph E. Yeatter, Ph.D., Game Specialist

Section of Wildlife Experimental Areas

Arthur S. Hawkins, M.S., Game Technician

F. C. Bellrose, Jr., B.S., Assistant Game Technician

John M. Anderson, B.S., Funior Biologist

\section{Cooperative Wildlife Restoration Program}

(State Department of Conservation and U.S. Fish and Wildlife Service)

Harry G. Anderson, M.A., Funior Biologist

L. G. Brown, B.S., funior Biologist

R. E. Hesse Lschwerot, B.A., Funior Biologist

\section{Section of Applied Botany and Plant Pathology}

L. R. TеноN, Ph.D., Botanist

D. B. Creager, Ph.D., Research Pathologist

J. C. Carter, Ph.D., Assistant Botanist

G. H. BoEwE, M.S., Field Botanist

\section{Section of Publications}

James S. Ayars, B.S., Editor

Consultant: Herpetology, Howard K. Gloyd, Ph.D., Director of the Museum, Chicago Academy of Sciences

This paper is a contribution from the Section of Applied Bntany and Plant Pathnlogy. 


\section{CONTENTS}

ACKNOWLEDGMENTS. . . . . . .

Review of Literature. . $\ldots \ldots \ldots \ldots \ldots$

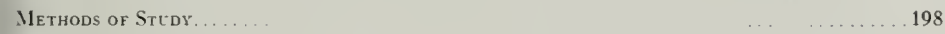

Ixcidence of OAK Diseases. $\quad \ldots \ldots 198$

Canker ano Dieback Diseases. . $\quad \ldots 200$

Dothiorella Canker and Dieback. $\quad .200$

Coryneum Canker and Dieback. . . 205

Cytospora Canker and Dieback... 206

Nummularia Canker and Dieback. 208

Diatrype Canker and Dieback .. 209

Phomopsis Canker and Dieback _... 211

Canker Diseases . . . . . . . . . 212

Phoma Canker.... $\quad .212$

Fusicoccum Canker. $\quad .214$

Sphaeropsis Canker... 215

Bulgaria Canker...... . . 217

Dieback Diseases.......... 217

Coniothyrium Diehack. . $\quad .217$

Pyrenochaeta Dieback — _ _. _218

Root Rot................ . .219

Armillaria Root Rot... $\quad .219$

Miscellaneot's Fungi ..... $\quad 221$

Cylindrosporium. . . $\quad .221$

Rhodosticta...... 222

Cephalosporium ... $\quad \ldots 223$

Nigrospora........

Cunninghamella......

Pestalotia....... ... . . 225

Chaetomium..... . . . 225

Alternaria ... $\quad .226$

Penicillium. . . . . . 226

SUMMARY . . . . . . . . . . . . . . . . . 227

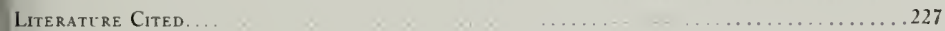




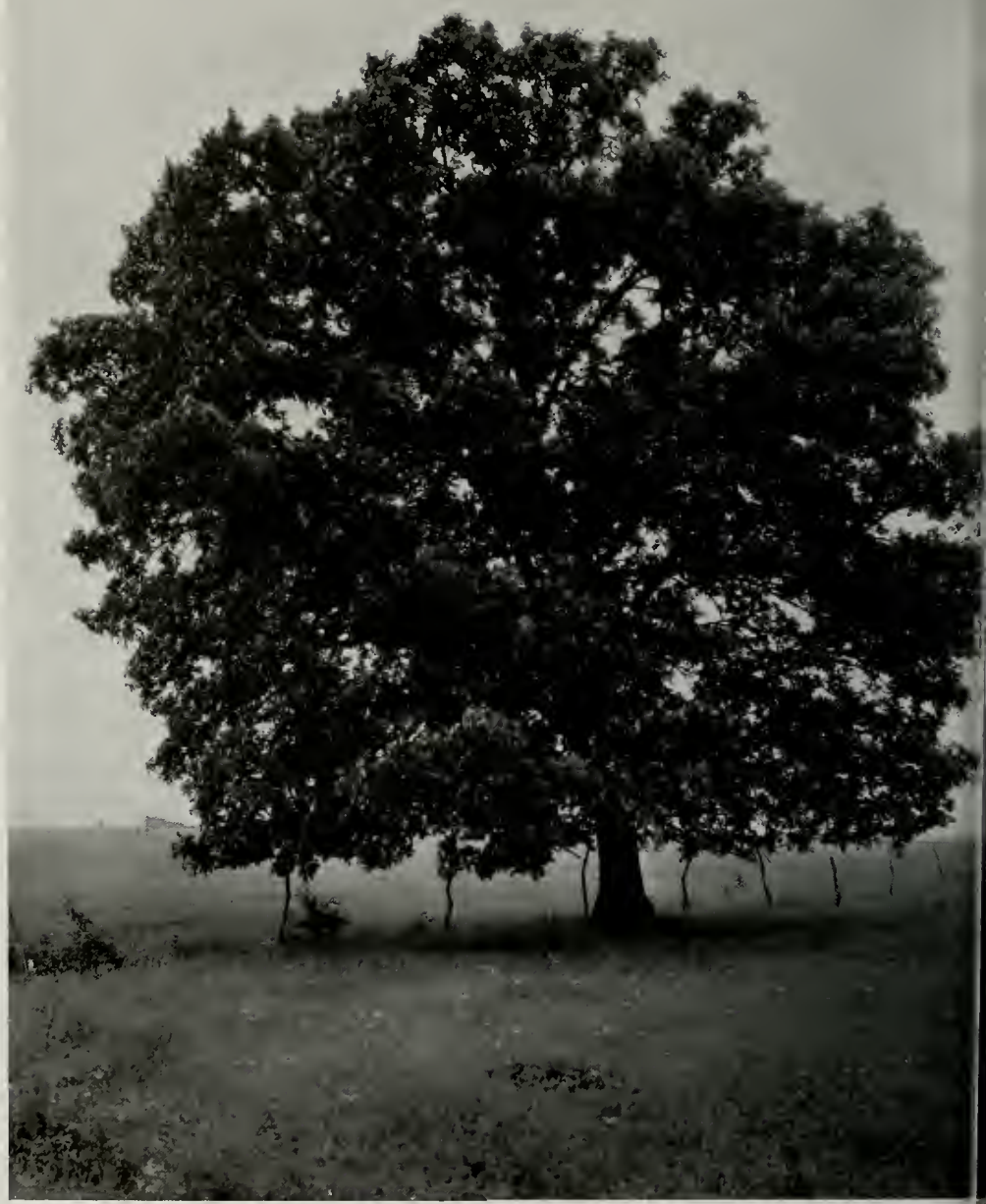

The bur oak, Quercus macrocarpa

Michx., is one of the several species of oak found in 1 llinois. Because native oaks are numerous throughout the state and have become increasingly popular, diseases of these trees are an important concern to Illinois citizens. 


\title{
Preliminary Investigation of Oak Diseases in Illinois
}

\author{
J. CEDRIC CARTER
}

I our investigation of tree diseases in Illinois the cases of disease of oak that have been brought to our attention have increased each year since 1934 . These cases have consisted mainly of canker and dieback diseases of small to large branches. Species of Gnomonia, Marssonia, Phyllosticta and Scptoria, some of the fungi that cause leaf diseases, have been studied by other investigators, and control measures have been recommended. Many heart-rot and a few root-rot fungi, namely, species of Armillaria, Fomes, $H_{y}$ dnum. Polyporus, Stereum and Ozonium, have been studied by others in relation to their parasitism of oaks. Only a few twig-blight and twig- and branch-canker producing fungi, principally $C_{y}$ tospora clirysosperma (Pers.) Fr., Diplodia longispora Cke. \& Ell., Nectria cinnabarina Fr., N. galligena Bres., $\mathbf{N}$. ditissima Tul. and Strumella coryneoidea Sacc. \& Wint., have been investigated by other workers.

The diseases of oak studied by the author and the fungi associated with them are described in this paper.

\section{ACKNOWLEDGMENTS}

The author wishes to express his sincere appreciation for the helpful assistance given to him during the course of this work. Through the cooperation of the Forest Preserve District of Cook County and many commercial nurseries in northern Illinois, he collected and studied many specimens of diseased oak material. Robert Everly of the Glencoe Park District, Glencoe, and George R. Pedlow of the Rockford Park District, Rockford, cooperated with the author in the study of the relationship of Armillaria mellea (Vahl.) Quel. to the infection of oaks. Much credit is given to G. H. Boewe,
Field Botanist of the Natural History Survey; William Ellsworth Rose, Village Forester, Hinsdale; H. F. Seifert, Chief State Plant Inspector of Illinois, and his assistants, William R. Jack, Glenn L. Pierce and John K. Karlovic; and to many others for their help in collecting diseased oak material. The author is indebted to Dr. Lewis E. Wehmeyer, Associate Professor of Botany at the University of Michigan; Dr. E. F. Guba, Research Professor of Botany at Massachusetts State College; and Dr. H. A. Edson, Principal Pathologist in Charge, Mycology and Disease Survey, U. S. Department of Agriculture, and his associates-Dr. J. A. Stevenson and 1)r. W. Wr. Diehl-for the identification of several of the fungi described in this paper. The photographic illustrations were produced through the willing cooperation of Ray R. Hamm, photographer for the University of Illinois. The examination of exsiccati was made possible by the Department of Botany, University of Illinois. The author is indebted to Dr. L. R. Tehon, Botanist and head of the Section of Applied Botany and Plant Pathology, Natural History Survey, under whose supervision the study was conducted, for suggestions and criticisms during the course of the work.

\section{REVIEW OF LITERATURE}

Internal disturbances of the living parts of oak trees have received very little attention by investigators of tree diseases. The "alcoholic Aux" or white slime Hux of oak was described by Ludwig (1886) and later reported by Massee (1907) at Kell. Ludwig (1888) also reported brown slime Hux of oak 2 years after he had described white slime flux. Slime Hux of oak was turther discussed by Tubeuf is Smith 
(1897), Holtz (1901), Ward (1901), Ogilvie (192t) and Guba (193t). An abnormal discoloration of oak wood, called "brown oak," was described by Groom (1915). He associated Melanogaster rariegatus Tul. var. broomianus Berk., a Penicillium-like fungus, with the production of the disease. Davidson (1935) observed that Fistulina hepatica (Huds.) Fr. was associated with the type of "brown oak" described by Groom. A recent investigation by Cartwright (1937) established the relationship of $F$. hepatica to the production of "brown oak." A vascular disease of trees, none of them oak, was first reported by Hartley \& Crandall (1935). This disease, since called wetwood, was later found in oak by Crandall, Hartley \& Davidson (1937), who isolated bacteria from the wood adjacent to the wetwood regions.

A bark disease of oak, called smooth patch, was described by 'Tehon \& Jacks (1933). They found Aleurodiscus Oakesii (B. \& C.) Cke. associated with smooth patch and believed it to be the cause of the disease. Craighead (1923) previously had attributed this type of injury to the larvae of Encyclops, and stated that these larvae have the peculiar habit of mining in the dry, corky outer bark of Quercus alba L. and other trees. Bark blotch of oak produced by Dichaena quercina Fr. was described by Massee (1910).

A trunk canker of Quercus rubra L. was described by Ludwig (1887) and attributed to Bulgaria inquinans (Pers.) Fr., considered by him a wound parasite. A basal canker of oak was reported on $Q$. Cerris L., $Q$. palustris Muench. and $\tilde{Q}$. rubra by Hennings (1894), who found B. polymorpha (Oeder) Wett. associated with the disease and pointed out that this fungus may attack and kill the bark of old trees. A trunk canker of oak attributed to Polyporus hispidus (Bull.) Fr. was described by Sleeth \& Bidwell (1937).

Twig and branch cankers of oak have received some attention. Hartig (1894) attributed a Nectria canker in the cortical tissue of oak and other trees to Nectria ditissima Tul. Buckhout (1900) reported a disease originating in crotches of black oak (Quercus tinctoria Bart.) and pin oak; he attributed it to $N$. ditissima. Zeller \& Owens (1922), Ashcroft (193t) and Clinton (193t) reported Nectria canker on oak and considered the disease to be produced by $N$. galligena Bres. Welch (1934a) reported Nectria canker, as caused by $N$. ditissima, on oak in Connecticut, Massachusetts, New Hampshire and Vermont. Kienholz \& Bidwell (1938) listed Nectria canker on black, chestnut, red, scarlet, scrub and white oaks in Connecticut and stated it was caused by Nectria coccinea (Pers.) Fr. and other Nectria species. Welch $(193+b)$ and Spaulding, Grant \& Ayers (1936) pointed out that no hardwoods are immune to attack by Nectria. Grant \& Spaulding (1939) recently pointed out that the avenues of entrance for the canker-forming species of Nectria on oak and other hardwoods in New England are branch stubs, cracks at the axils of branches, and rubbing injuries, as well as other avenues of infection not determined.

Strumella canker on oak, with which Strumella coryneoidea Sacc. \& Wint. is associated, was found by Anderson (1922) in Illinois in 1919. Strumella canker was also reported on oak by Bidwell \& Bramble (193t), Bramble (193t), Clinton (1934), Davis (1935), McKenzie (1937), Kienholz \& Bidwell (1938) and others (Anonymous 1934). Heald (1914) and Heald \& Studhalter (1914) pointed out that there are two forms of Strumella infection. One form produces cankers and the second form causes a diffused type of infection. In this latter type of infection the fungus spreads rapidly in the tree without callus production, and the tree dies quickly. Cytospora chrysosperma (Pers.) Fr., the willow canker fungus, was reported by McKenzie (1937) to be the cause of a canker on oak. Two years earlier, Cytospora sp. (Humphrey \& Wood 1935) was reported to be the cause of canker on oak in New Jersey. A canker on oak described by Hartig (1894) was attributed by him and by Henry (1902) to Aglaospora ialeola Tul., considered Diaporthe taleola (Fr.) Sacc. by Massee (1910) and by Moreillon (1918). Moreillon pointed out that, in Switzerland, twigs up to one-half inch in diameter and 20 inches long were affected with $D$. taleola. A nut rot of red oak was attributed by Orton (1908) to "Sphaeropsis quercina" Cke. \& Harkn.

Twig blight and canker of chestnut oak, Quercus Prinus L., is becoming in- 
creasingly important. The blight, found occasionally on $Q$. alba as well as on $Q$. Prinus, was reported in 1912 and described in 1914 by Ingram (1912, 1914), who demonstrated that Diplodia longispora Cke. \& Ell. is the fungus responsible for the disease. Ingram (191t) stated that infection occurs through wounds in the bark and that the fungus, after penetrating the twig, does not extend into the leaves. Small trees are killed outright; large trees are weakened by loss of young branches and die later. This twig hlight was reported on O. Prinus and other species of oak by Haensler (1932), Clin10.) (1934), Davis (1935) and White (1936). In 1935 it was found on $Q$. alba in California, Maryland, Texas and $\mathrm{W}$ isconsin (Edson \& Wood 1936). Four years later, it was reported on Quercus in lowa, Massachusetts, Virginia and West Virginia by Waterman (1939). A similar twig blight has been attributed to Sphaeropsis malorum Berk. by Rankin (191t) and others (Anonymous 1930, 1931).

Botryodiplodia Ravenellii Sacc. was found by Babcock $(1915,1916)$ to be the cause of twig blight on scarlet oak in the vicinity of Cincinnati, Ohio, and to attack the host through bark wounds. Doilhidea noxia Ruhl. was reported on oak by Ruhland (190t). He stated that it attacked the living cortex of twigs and branches of oaks, and that it was especially noticeable in young trees. The conidial stage of this fungus he called Fusicoccum noxium Ruhl. $D$. noxia has since been reported on American oaks in Europe by Bavendamm (1936). A tumor disease of oaks and hickories in the United States, attributed to a species of Phomopsis, was described by Brown (1938). Other fungi, that are mentioned by Boyce (1938) and that appear to be related to canker diseases of oak, are Stereum rugosum Pers, and Fomes igniarius (L.) Gill in Germany and F. robustus Karst, in France.

Ten genera of fungi were reported by Carter (1938) associated with branch diseases of oak: Bulgaria, Coryneum, Cytospora, Diatrype, Phoma, Phomachora, Rhodosticta, Spaeropsis and Ustulina.t From diseased specimens of oak Carter isolated the fungi Alternaria, Armillaria,

* Dolhiorella, as described in this paper.

$\dagger$. I ummularia, as described in this paper.
Coryneum, Cytospora, Fusarium, Penicillium, Phoma, Phomachora, * Phomopsis and Ustulina.†

Other genera of fungi that are helieved to cause twig and branch diseases of oak include Pseudoz'alsa and Coryneum. Pseudor'alsa longipes (Tul.) Sacc. was reported on oak by Henry (1902). Wehmeyer (1926) reported $P$. longipes on twigs of Q. coccinea Muench. and studied the cultural life history of this fungus and its imperfect stage, Coryneum Kunzei Corda. P. sigmoidea (Cke. \& Ell.) Sacc., which Wehmeyer believed to be synonymous with $P$. longipes, and an unidentified species of Coryneum were reported in Fort Worth, Texas, by Tauhenhaus \& Ezekiel (1932), who suggested that the Coryne$\mathrm{um}$, which was causing injury to live oak, might be a stage of $P$. sigmoidea; they found both forms fruiting on the same diseased tree. A stem blight of $O$. virginiana Mill. in Texas was first reported in 1934 and attributed to Trabutia eryihrospora (B. \& C.) Cke. by Taubenhaus (1934, 1935). Death of three pin oaks and one willow-leaf oak on the Kansas State College campus in 1933 and 1934 was associated with Diatrype stigma (Hoffm.) Fr. by Lefebrre \& Johnston (1935). Atkinson (1897) had previously reported the same fungus on dead oak branches at Auburn, Alabama. Godroniopsis Quernea (Schw.) Diehl \& Cash was reported by Overholts (1934) on living branches of $Q$. coccinea. Fistulimt hepatica (Huds.) Fr. was found by Hartig (1894) to be the cause of a reddish-brown wood rot of oak and was suggested by Braid (192t) as a major factor in the production of staghead and hollow tree of oak. Weir (1925) reported that Endothia gyrosa (Schw.) Fr. was capable of causing a root disease of $Q$. velutinn Lam.

Numerous studies have been made on the relationship of Armillaria mellea (Vahl.) Quél. to the decline and death of oaks and other trees. Thomas (193t) reported that the fungus is capable of invading the roots through the sound and healthy periderm by a combination of mechanical and chemical means. Campbell $(193 t)$ maintained that the black zone lines produced in the infected roots by this fungus are actually sheets or plates of black strands, which he called pseudosclerotia. Rhizomorphs of A. mellea are 
present and often widespread in soils covered by natural oak stands. Numerous control measures have been suggested and recommended, but none of these has proved to he completely satisfactory (Horne 1914, 1915, 1919, Newman 1926, Rankin 1927, Brooks 1928, Owens 1928, Hubert 1931, Kendall 1931, Felt \& Rankin 1932, Heald 1937 and Boyce 1938).

The parasitic nature of most of the above fungi has not been proved. A large majority of these fungi, which have been reported on living oak trees, have been associated with cankers on twigs and branches. These twig and branch cankers, in the later stages of their development, frequently result in twig blight or branch dieback.

\section{METHODS OF STUDY}

To study the parasitism of various fungi that might be associated with the diseases of living oaks it was necessary to examine many diseased specimens. Culture tests were made in order to isolate the organism that was present in the diseased tissue of each specimen. Wood pieces for culture tests were taken from diseased living tissue and from diseased dead tissue that had been only recently killed, and isolations were made of those fungi that were sporulating on the dead tissue.

The fungi present in the diseased specimens were isolated in the following manner. A diseased specimen, including the bark, was sterilized in 0.1 per cent mercuric chloride for 1 to 2 minutes, and then thoroughly rinsed in sterile water. After the bark was removed, several slices were cut from the diseased wood with a sterile scalpel. With sterile forceps some of the slices were planted directly on Difco corn meal agar in Petri dishes. The others were sterilized individually by being dipped in and out of a 0.1 per cent mercuric chloride solution. Then they were washed in two changes of sterile water and planted on the agar in the Petri dish with the unsterilized slices. A similar procedure was followed in making isolations from diseased bark.

Single-spore plantings were made of the fungi found fruiting in the cankerous tissue. These plantings were made by sterilizing the cankerous tissue, which contained the fungus, in 0.1 per cent mercuric chlo- ride for 30 to 60 seconds. The fruiting structures were then removed with a sterile scalpel and placed in a large drop of sterile water on a flamed microscope slide. The fruiting structures were crushed, placed in suspension and agitated to liberate the spores. A sterilized bacteriological loop was used to transfer the spores in suspension to agar in Petri dishes. The spores were planted in streaks across the agar. Widely separated spores on the agar, that were visible with the low power of the microscope, could be located and their positions marked. After the spores had started to germinate they were easily removed, with a small amount of the surrounding agar. A sterilized, bacteriological, spatula-tipped wire was used to remove these germinating spores, and they were placed on sterile agar in Petri dishes for further development.

Some histological studies were made of the diseased tissues. Some of the fungi associated with canker and with dieback grew and progressed slowly in the host tissues. It is quite possible that other fungi of secondary importance were present in these diseased tissues. In such cases histological studies would be of very little value. Careful examinations were made of living xylem from which Dothiorella and Coryneum had been isolated. Cartwright's (1929) method of staining fungal mycelium in wood sections was followed in this investigation.

\section{INCIDENCE OF OAK DISEASES}

Diseases of oaks and other trees have not received so much attention and consideration as have the diseases of field crops, vegetables, fruits and similar economic plants. However, in recent years the importance of tree diseases has been forcefully brought to our attention by the destruction of the American chestnut and by the widespread dying of the American elm. The destruction of trees by disease is an economic and aesthetic loss to the inhabitants of large areas of the United States. Because native oak forests and groves are numerous throughout lllinois, and because oaks for shade and ornamental purposes are receiving more attention than formerly from nurserymen and home owners, diseases of oaks are now an important concern to the people of the state. 
In this investigation, diseased trees were found among native, shade, ornamental and nursery plantings of oak, including Quercus alba L. (white oak), $Q$. bicolor IVilld. (swamp white oak), $Q$. borealis maxima Ashe (red oak), $O$. ellipsoidalis E. J. Hill (Hill's oak), Q. imbricarin Michx. (shingle oak), Q. macrocarpa Michx. (bur oak), O. marilandica Muench. (black jack oak), $Q$. Muhlenbergii Engelm. (chinquapin oak), $Q$. palustris Muench. (pin oak), $Q$. stellata Wang. (post oak) and Q. zelutina Lam. (black oak). Future reference to these oak species will be made by common name. The diseases considered in this investigation are those of the twigs, branches and to some extent the trunks of living trees. The much-studied heart rots and leaf diseases, as well as the root diseases, have received very little attention in the present study. However, it has been necessary to give some consideration to shoestring root rot caused by Armillaria mellea (Vahl.) Quél.

The diseases most frequently observed on the wood of living oak trees in Illinois are known as cankers, dieback and staghead. Although wilts of elm and maple are common, wilt of oak is very unusual. On oaks, the development of cankers as well as the progress of dieback and staghead is very slow. The slow progress of these diseases, which each year spread only a few inches in some cases to a few feet in others, is ideal for the growth and fructification of parasitic fungi. Furthermore, saprophytic fungi may attack and develop on and in the dead and dying tree parts.

It is not uncommon to find that the same fungus is associated constantly with the perennial development of a canker or dieback on an oak branch. The frequency and consistency with which numerous fungi have been associated with the diseases of oaks leave no doubt of their importance in the occurrence, prevalence and spread of the diseases.

The diseases under consideration in this bulletin occur as cankers, dieback and root rot. Cankers are found on twigs and branches of trees of various sizes and on trunks, principally, of small trees. Dieback is found on twigs and branches. Deep wood infections, associated with both canker and dieback diseases, are found mainly on medium to large branches. The blighting of leaves and twigs, which usually results in twig cankers or dieback, is quite prevalent throughout the state. Often, differentiation between cankers and dieback is difficult because many cankers continue to grow and spread year after year, and frequently branches are entirely encircled by them. After a canker has encircled a branch, subsequent dying may develop as dieback, as in Dothiorella canker and dieback. In some cases, when the twig is affected with dieback, the whole twig is killed, and the causal agent continues to grow and to spread into the branch at the base of the twig. From this type of infection a branch canker may develop with the dead twig for the original region of infection, fig. 27 . Differentiation between canker and dieback seems to depend more on the physical appearance of the diseased region than on the infectious agent.

In the study of diseased specimens obtained for examination, an attempt was made to associate specific syinptoms with a specific fungous parasite. Accomplishment of this purpose was impracticable, because each of several fungi was associated with cankers, dieback and wig blight. The external and internal characters of several cankers may appear to be identical. but the causal organisms associated with these cankers may represent several species of fungi. This situation holds true for dieback and twig blight, as well as for cankers, and makes practically impossible an accurate field diagnosis of the cause of a given branch disease of oak.

Twelve genera of fungi were found fruiting on the cankerous tissues of 80 of the diseased oak specimens that were studied. These genera and the number of specimens infected by each genus are given in table 1.

Of the fungi observed fruiting on the 80 specimens, Dothiorella and Coryneum were prevalent, as shown in table 1 . Dothiorella comprised +2.50 per cent and Corynenm 21.25 per cent of the specimens. Ten genera, namely, Cytospora. Phoma, Diatrype, Nummularia, Fusicoccum, Bulgaria, Cylindrosporium, Phomopsis, Rhodosticta and Sphaeropsis, comprised the remaining 36.25 per cent.

A list of the genera of fungi obtained in culture from 284 specimens of diseased oak and the frequency of the appearance 
of each genus may be observed in table 2 . Although Dothiorella was secured in the fruiting stage from only 6 specimens, a fungus which appeared similar to singlespore cultures of Dothiorella but which did

Table 1.- Genera of fungi found fruiting in the cankerous oak tissues of 80 specimens.

\begin{tabular}{|c|c|c|}
\hline Genus & $\begin{array}{l}\text { Number of } \\
\text { SPECIMENS } \\
\text { INFECTED }\end{array}$ & $\begin{array}{l}\text { Per Cent of } \\
\text { SPECIMENS } \\
\text { InfECTED }\end{array}$ \\
\hline 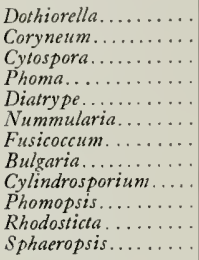 & $\begin{array}{r}34 \\
17 \\
7 \\
6 \\
4 \\
4 \\
2 \\
2 \\
1 \\
1 \\
1 \\
1\end{array}$ & $\begin{array}{r}42.50 \\
21.25 \\
8.75 \\
7.50 \\
5.00 \\
5.00 \\
2.50 \\
2.50 \\
1.25 \\
1.25 \\
1.25 \\
1.25\end{array}$ \\
\hline Total. ........ & 80 & 100.00 \\
\hline
\end{tabular}

Table 2.- Genera of fungi obtained in culture from 284 specimens of diseased oak, arranged according to frequency of appearance.

\begin{tabular}{|c|c|c|}
\hline Genus & $\begin{array}{c}\text { Frequency } \\
\text { OF } \\
\text { APPEARANCE* }\end{array}$ & $\begin{array}{l}\text { Per Cent of } \\
\text { TOtal } \\
\text { APPEARANCES } †\end{array}$ \\
\hline 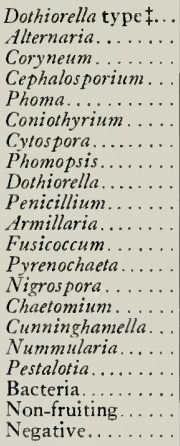 & $\begin{array}{r}135 \\
38 \\
29 \\
27 \\
25 \\
17 \\
16 \\
9 \\
6 \\
6 \\
4 \\
4 \\
3 \\
2 \\
1 \\
1 \\
1 \\
1 \\
28 \\
65 \\
16\end{array}$ & $\begin{array}{r}31.11 \\
8.76 \\
6.68 \\
6.22 \\
5.76 \\
3.92 \\
3.69 \\
2.07 \\
1.38 \\
1.38 \\
0.92 \\
0.92 \\
0.69 \\
0.46 \\
0.23 \\
0.23 \\
0.23 \\
0.23 \\
6.45 \\
14.98 \\
3.69\end{array}$ \\
\hline Total....... & 434 & 100.00 \\
\hline
\end{tabular}

*The number of specimens from which each genus was cultured out of the total 284 diseased specimens examined. In several instances more than one genus was cultured from a single diseased specimen.

tPer cent of tolal appearances is calculated on the lotal frequency of appearance, which is 434

$\ddagger$ This fungus appears to be identical with Dothiorella, below in the table, but did not produce fruiting structures in culture. not develop fruiting structures was obtained in culture from a total of 135 specimens. This fungus, which is believed to be Dothiorella, showed a frequency of appearance of 31.11 per cent and was obtained from $47.5+$ per cent of the $28+$ diseased specimens. 1t was not uncommon to obtain Dothiorella and other fungi from the same specimen of diseased wood. The isolation of more than one fungus from a single specimen is pointed out in the discussion of the respective fungi.

Coryneum was obtained in culture from 29 different specimens, Phoma from 25 specimens, Coniothyrium from 17 specimens and Cytospora from 16 specimens, table 2. The combined frequency of appearance of these four fungi, Dothiorella and Dothiorella type represents approximately 53 per cent of the total appearances. The remaining 47 per cent is composed of more than 13 other fungi.

Although Alternaria shows a frequency of 38 and Cephalosporium a frequency of 27 , they are not considered important, as they were obtained from diseased living oak tissue in only a few cases-Alternaria in one case and Cephalosporium in five cases.

The repeated association of Dothiorella, Coryneum, Phoma, Cytospora, Coniothyrium, Phomopsis, Fusicoccum, Nummularia and Diatrype with diseases of oak indicates that these fungi are important in the occurrence and development of the diseases with which they are associated.

\section{CANKER AND DIEBACK DISEASES}

\section{Dothiorella Canker and Dieback}

A Dothiorella canker and the resultant dieback are shown on a pin oak specimen in fig. 1. The cankerous bark is dark brown to almost black, collapsed and shrunken. The formation of fissures in old cankers is due to the arresting of tissue development, the drying out, and the splitting that occurs between the dead tissue of the canker and the adjacent living tissue. It is clear from fig. 2 that the stromata of Dothiorella develop abundantly in the cankerous bark and that they are erumpent at maturity. Fig. 3 shows the dark brown to black discoloration of the xylem, which occurs beneath the cankerous bark. This discoloration progresses down the branch in the 
living tissue from 1 to 10 inches beyond the lower extremity of the cankerous region. The streaks of discoloration in the xylem vary in size. Some streaks are so small as to be just visible, while others are approximately $2 \mathrm{~mm}$. in diameter. In some cases the streaks coalesce and form solid regional discolorations.

Dothiorella was associated with branch cankers and dieback of 40 diseased specimens collected throughout Illinois from black, pin, red and white oaks. Indications are that the growth of the fungus is perennial; the cankers continue to progress in their development for several years. Branches that show dieback continue to die year after year until the whole branch is killed. In many instances infection occurs first on twigs and small branches. These infections spread and involve the larger branches when the originally infected part has been killed.

The pycnidia of Dothiorella vary in their development from single pycnidia to aggregated pycnidia in a pulvinate stroma. In fig. $t$, pycnidial chambers are shown in the vertical section of a stroma. The fruiting structures are laid down in the phellogen-phelloderm tissues of the branch, and their development causes a separation of these tissues accompanied by very little cellular disintegration. Further development to maturity ruptures the overlying phellem and epidermis. These tissues are forced back to form oral to round openings with shielded sides. The erumpent stromata are visible through these openings, as shown in fig. 2.

Mature stromata of Dothiorella in the cankerous bark are dark brown to black. sessile, dothideoid, erumpent, 600-1300 $\mu$ in diameter and $+00-500 \mu$ high. The pycnidial walls for the most part fuse to form the stromatic tissue. The prcnidial carities are globose to ovoid, $1+5-300 \mu$ in diameter, and open by individual, circular ostioles $15-30 \mu$ in diameter. Conidiophores are hyaline, simple, $6-15 \times$ 2.8-3.4 $\mu$, and papillate. The conidia, shown in fig. 5 , are continuous, hyaline. 15-26 $\times 9-15 \mu$, and ovoid. 'The content of each spore is granular.

A culture of Dothiorella, grown from a single-spore isolation on corn meal agar, is shown in fig. 6 . The fungus produces an exceedingly sparse mycelial growth with gray aerial hyphae, gray to very light $\tan$ surface hyphae and gray-black to tan subsurface hyphae. A single germ tuhe from

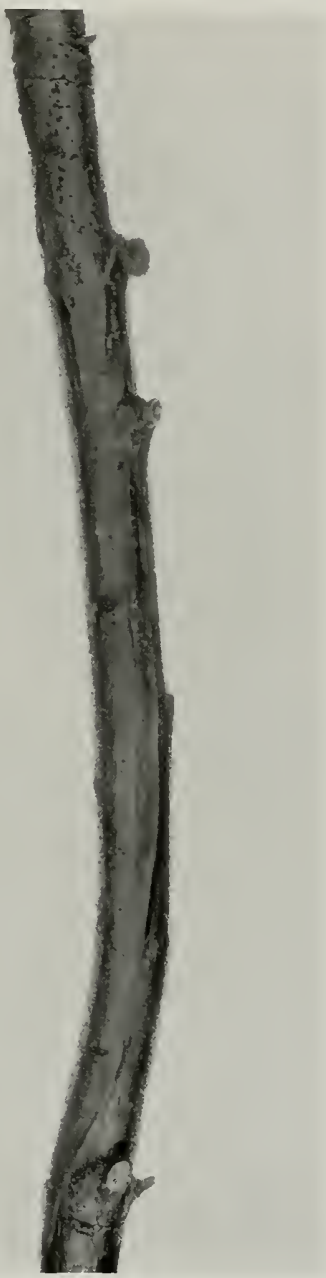

Fig. 1.-Dothiorella canker and dieback on pin oak. The smooth, sunken, brown to almost black, diseased region, shown at the left of the branch, contains numerous black, erumpent stromata of Dothiorella. I $3 / 4$. 
each spore pushes out as an evagination of the spore cell wall, and the cell contents pass from the spore into the germ tube.
Spore germination as high as 66 per cent occurs in approximately 10 hours. This high germination percentage is obtained
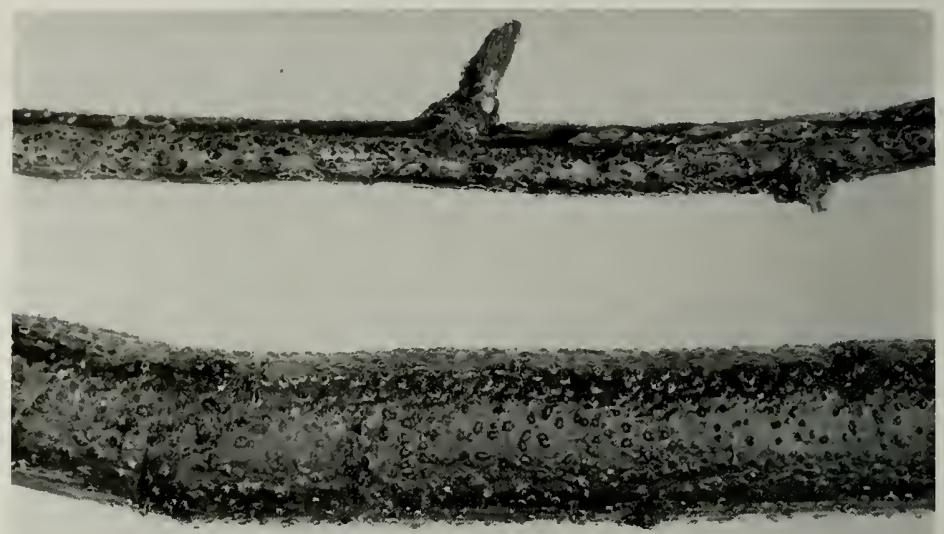

Fig. 2.-Dothiorella dieback on red oak. The brown to black, cankerous bark of each branch contains numerous black, erumpent stromata of Dothiorella. $\mathrm{X} 2$.
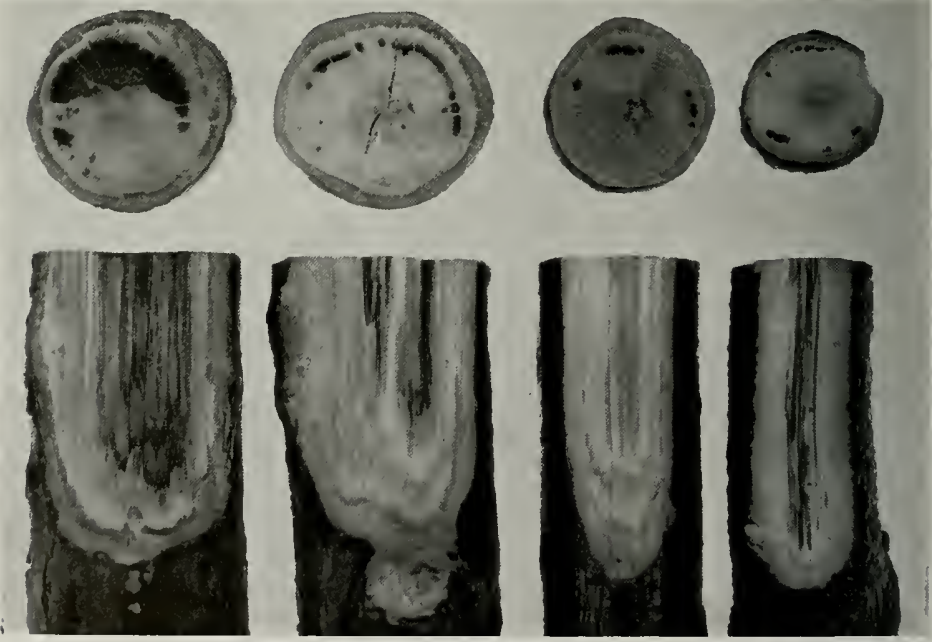

Fig. 3.-Wood discoloration of white oak associated with Dothiorella infection. Discoloration of the xylem tissue is characterized by fine to broad streaks that frequently coalesce and appear as solid regional discolorations. $\mathrm{X} 12 / 3$. 
when the spores are suspended in sterile, distilled water on a microscope slide and when the slide is maintained in a moist atmosphere. Single-spore colonies on corn meal agar produce an average diameter growth of $+6 \mathrm{~mm}$. in 8 days, or an average

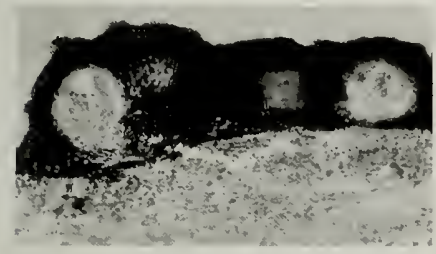

Fig. 4. A stroma of Dothiorella. The blact stromatic tissue and pycnidial cavities that contain spores are shown in vertical section. × 50 .

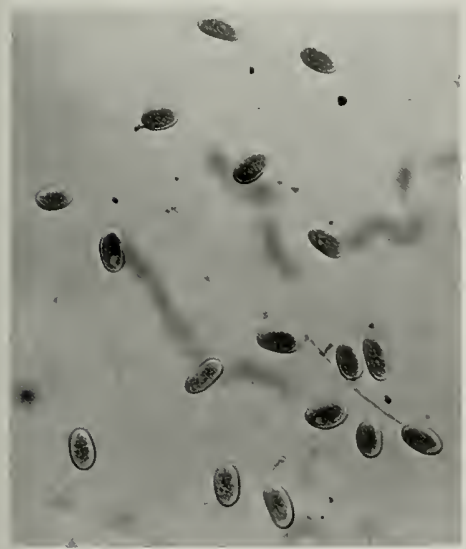

Fig. 5. Spores of Dothiorella. The spores are continuous, hyaline and ovoid. I 300.

daily diameter growth of $5.8 \mathrm{~mm}$. Germ tubes reach a length of approximately 188 $\mu$ before any branching occurs.

Cultures of Dothiorella grown from single-spore isolations failed to produce fructifications on artificial media or on sterilized wood of white oak. However, fructifications of Dothiorella developed on the naturally infected wood pieces that were placed on corn meal agar.
Dothiorella was isolated from five diseased oak specimens affected with twig blight. Two of the five isolations were obtained from black oak: one from discolored living wood of a twig and one from a blighted petiole. Three were obtained

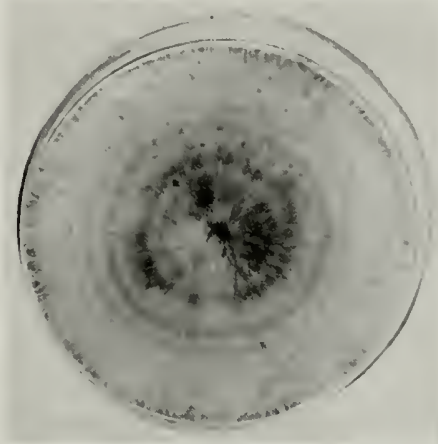

Fig. 6.-Culture of Dothiorella. On corn meal agar, this fungus produced gray to tan mycelium without stromata.

from pin oak: two from blighted petioles of two separate specimens and one from a twig. In the above cultures the fructifications varied from a pycnidium with one chamber to compound pycnidia in a stroma. The fructifications are hlack, oroid, ostiolate, pseudoparenchymatous, and 260-530 $\mu$ in diameter. They contain conidia that are 18-25 $\times 12-17 \mu$, hyaline, ovoid and continuous. The conidiophores are hyaline, $12-16 \times 2.8-3.4 \mu$, papillate and unliranched.

Microscopic examination did not reveal the presence of fungous hyphae in the discolored regions of the xrlem, fig. 3. Many of the trachea and parenchyma cells appeared to be partially filled with a granular material, and many of the cell walls were dark and evidently were not stained.

The Dothiorella described in this paper was previously ralled Phomachora by Carter (1938). Our material agrees with Dothiorella quercina (Cke. \& Ell.) Sacc. as represented in Shear's New York Fungi No. 373.

Other fungous cultures from 135 specimens of diseased oak appeared to be identical with Dothiorella in every respect ex- 
cept that they did not fructify on artificial media, on sterilized oak twigs or on sterilized clover stems. They were isolated from 10 species of oak, namely, black, black jack, bur, chinquapin, pin, post, red, shingle, swamp white and white. They were grown from bark and wood of cankers, some with and some without Dothiorella stromata in the bark, from dieback specimens, from blighted petioles and twigs, and from deep wood infections. The deep wood infections were conspicuous because they showed dark brown to black discolored regions, illustrated in fig. 3. Over 50 per cent of the fungi cultured from the deep wood infections were similar in appearance to Dothiorella. However, it cannot be conclusively stated that these cultures were Dothiorella, since fructifications did not occur.

Inoculation Trials.-On March 8, 1937, three white oaks, grown in flower pots in the laboratory, were inoculated with living cultures of Dothiorella. The method of inoculation was, in general, that described by Carter (1936) in the inoculation of American elms with Cytosporina ludibunda Sacc.

By March 20, 1937, leader tips of two of the three inoculated trees had started to die. By April 23 each of the two dying trees had 3 inches of its leader tip dead. The third tree showed dying back of the leader tip by May 1. All three trees were dead by July 1, 1937; however, at that time no stromata of Dothiorella had developed in the dead bark.

Stromata were first observed in the dead bark of one of the above three trees on March 24, 1938, when attempts were made to reisolate Dothiorella from each of the three trees. These stromata were brown to black, globose to ovoid, pseudoparenchymatous, dothideoid, $600-800 \mu$ in diameter and $450-530 \mu$ high. They contained from one to several pycnidia, and the pycnidial walls, for the most part, formed the stromatic tissue. The pycnidia were immature, and conidia developed in only a few pycnidia. These conidia were hyaline, $18-23 \times 12-16 \mu$, ovoid, continuous, and had granular contents.

Dothiorella was reisolated in pure culture from each of the three inoculated oaks. The reisolated Dothiorella did not produce stromata on artificial media. However, it did produce stromata on ster- ile white oak wood and on sterile clover stems. The oak wood and clover stems were partially submerged in corn meal agar in test tuhes. Approximately 6 months were required for the stromata to develop. These stromata were ovoid, black, ostiolate, pseudoparenchymatous, and 775$825 \times 625-675 \mu$. The pycnidial cavities were $350-670 \mu$ in diameter, and the conidia were ovoid, hyaline, $18-22 \times 12-$ $16 \mu$, continuous, and had granular contents. The reisolated Dothiorella was identical in appearance with the original isolate.

A second series of inoculations, previously reported by Carter (1940), was made, June 20, 19+0, on nine oaks (three each of black, red and white oaks) located in the experimental nursery of the Natural History Survey. Dothiorella infection of these trees occurred, and within 3 weeks after the trees were inoculated bark was dying around the inoculated regions. Canker and dieback developed with external and internal symptoms identical to those described above as the characteristic symptoms of Dothiorella canker and dieback. Stromata of Dothiorella appeared in the infected bark within 7 weeks after inoculation but had not become erumpent by the end of 9 weeks.

Dothiorella was reisolated in pure culture from representative trees of each of the three species of oak on August 17, 1940. The reisolated Dothiorella was identical with the original isolate.

Adequate check trees were maintained for both the 1937 and the 1940 series of Dothiorella inoculations. In no instance was Dothiorella cultured from the check trees.

\section{Coryneum Canker and Dieback}

Coryneum cankers develop on twigs and small to large branches of oaks of various sizes, and occasionally on trunks of small oak trees. They are found most frequently on small branches. The diseased tissues of Coryneum canker and dieback are reddish brown; the cankerous region is somewhat sunken and is dotted with erumpent acervuli of the fungus, as may be seen in fig. 7. The borders of the canker are sharply defined by the contrast in color of the healthy and diseased tissue and by the shrinking of the cankerous bark. Inter- 


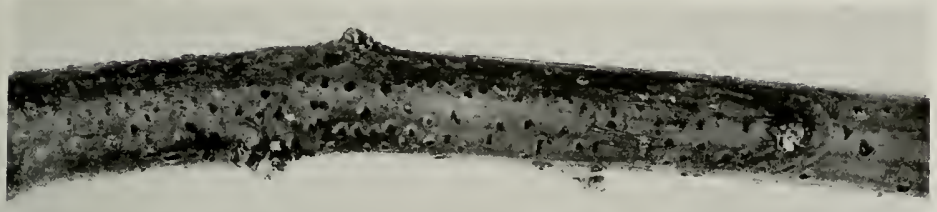

Fig. 7.- Coryneum canker and dieback on red oak. The section of a diseased hranch pictured here shows black, erumpent acervuli in the reddish-brown, shrunken bark. $\mathrm{X}^{3} \mathrm{~s}$.

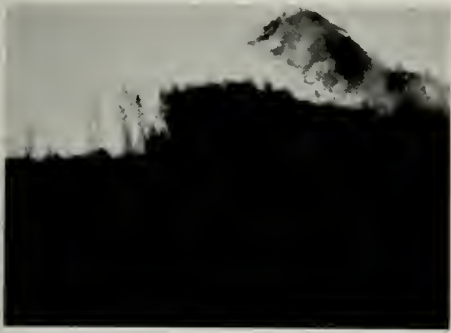

Fig. 8.- Portion of an acervulus of Coryne$u m$. Several attached spores and the broken host tissue are shown on the upper portion of the acervulus. I 100 .

nally the cankerous tissue is light brown, and the discoloration in the xylem does not progress over $2 \mathrm{~cm}$. heyond the external cankered region. From observation it seems quite evident that $C o r y$ neum grows year after year and that the cankers progress down the branch. Not infrequently a canker encircles a branch and develops into dieback, which may progress to the base of the branch. In a few cases Coryneum was associated with twig hlight. Coryneum canker and dieback was found on pin, red and white oaks. 'The fungus Coryneum was grown from cankerous bark, discolored wood, blighted twigs and living wood adjacent to developing cankers on post, shingle, red, swamp white and white oaks.

The acervulus of Coryneum is laid down fundamentally in the phellogen-phelloderm region of the bark. Development of a compactly interwoven hyphal mass, the base of the acervulus, causes a separation of the associated tissues that is accompanied by very little cellular disintegration. Further development of the acervulus, especially about the time conidia are pro-

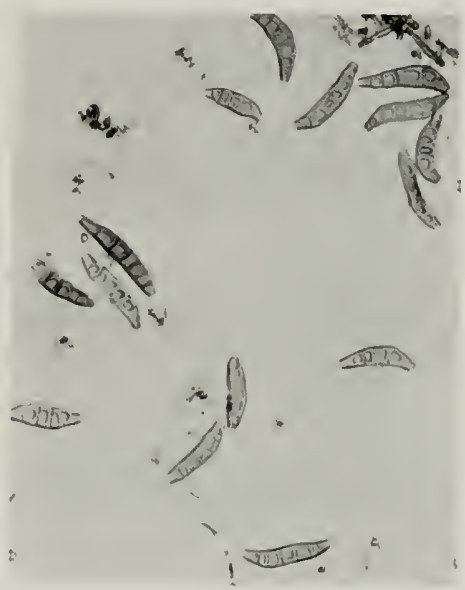

Fig. 9. Spores of Coryneum. Fach tip cell and base cell of the tan to olive-brown, curved spores are hyaline. X 230.

duced, ruptures the overlying phellem, epidermis and cuticle, forcing these tissues hack; the result is a more or less triangular opening through which the black acervulus is visible. A portion of an acervulus in vertical section, with attached conidia, is shown in fig. 8 . The erumpent acervuli are dark brown to black, discoid or pulvinate, compact, 1000-1500 $\mu$ in diameter and $260-400 \mu$ high. Conidia are shown in fig. 9. They are 3-to 6-septate, not constricted at septa; they are curved, clavate or narrow-fusiform, tan to olive brown, $+(0-80$ $\times 9-18 \mu$, with each tip and base coll hyaline. The conidiophores are $15-30 \times$ 3-t $\mu$, straight to slightly curved, lyaline to brown and few-septate.

Single spores of Coryneum planted on 
corn meal agar give rise to slowly spreading, dense mycelial growth. A culture of Coryneum is illustrated in fig. 10. The surface and aerial growth is bluish gray with a margin, approximately $1 \mathrm{~mm}$. wide, of white hyphae. The subsurface growth as greenish gray. Sporodochialike, grayishbrown acervuli arise promiscuously over the surface of the older portions of the

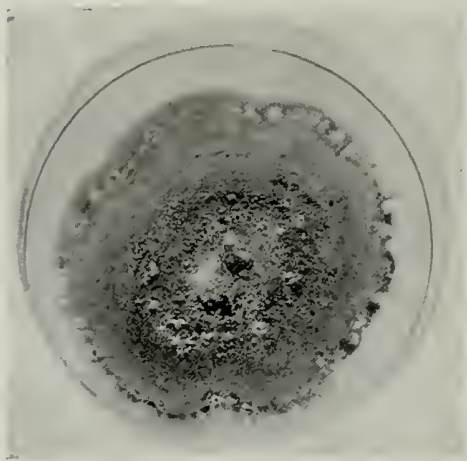

Fig. 10.-Culture of Coryneum. The fungus grows slowly and produces gray to tan mycelium on corn meal agar. Acervuli and spores develop on old cultures when the agar becomes dry.

culture. Typical tan to olivaceous-brown conidia arise from the acervuli and are interspersed with aerial hyphae. Growth of colonies from single-spore plantings increased radially about $1.6 \mathrm{~mm}$. each day for a period of 28 days. In culture the acervuli are 1200-1600 $\mu$ longitudinally and $650-675 \mu$ vertically, and the conidia are $+0-90 \times 12-19 \mu$. In shape and color, acervuli and conidia that developed in culture are similar to those that developed on the branch. Coryneum has not only been grown in culture from single-spore transplants but it also has been isolated from cankerous bark and from discolored living sapwood beyond the diseased tissue of cankers.

The identification of this fungus as $C a r$ yneum Kunzei Corda (Wehmeyer 1926) was verified by Dr. Lewis E. Wehmeyer.

Microscopic examination of branches of red oak infected with Coryneum showed no evidence of the fungus in the xylem tissue.
Inoculation Trials.-Three white oaks were inoculated with Coryneum on March 8, 1937. The procedure followed is that described on page $20+$ for the Dothiorella inoculation trials.

Two of the three trees showed dying of the leader tips by March 20. A gradual dying back of these two trees progressed rapidly from tip to base, and by April 1 they were dead. Culture tests were not made from these trees until March 2t, 1938. Coryneum acervuli did not develop in the bark of the dead trees during the period from April 1, 1937, to March 2t, 1938 , and no fungus was obtained in culture tests from these two trees. The third tree inoculated with Coryneum showed no signs of infection by February 1, 1939. Adequate check trees were maintained for this series of Coryneum inoculations. In no instances was Coryneum cultured from the check trees.

\section{Cytospora Canker and Dieback}

Cytospora canker and dieback was found on red oaks in the northeastern section of Illinois. Isolations of $C_{y}$ tospora were obtained from cankerous bark, diseased wood, blighted petioles and twigs, and discolored living wood adjacent to developing cankers on black, pin, red and white oaks. Cytospora canker and dieback on a black oak branch is shown in fig. 11. The cankerous tissue is sunken and varies from light to dark brown; few to many scattered erumpent stromata appear in the bark. The stromata appear as small, circular, black spots. Stromatic regions appear oval to elongate when two or more stromata fuse. Shrinkage of the cankerous tissue causes the irregular margin of the canker to appear raised. Internally the diseased xylem is light brown above and below the base of the canker; the woody tissue beneath the cankerous bark is discolored and varies from dark brown to almost black. The fungus develops year after year, and the cankers continue to spread down the infected branches. A gradual drying out and dieback of the branches result when they are completely girdled by the cankers.

The stromata are laid down in the cortex just beneath the phelloderm. As the interwoven hyphal mass continues to develop, the outer cortical cells disintegrate, the stromata develop laterally, and the 


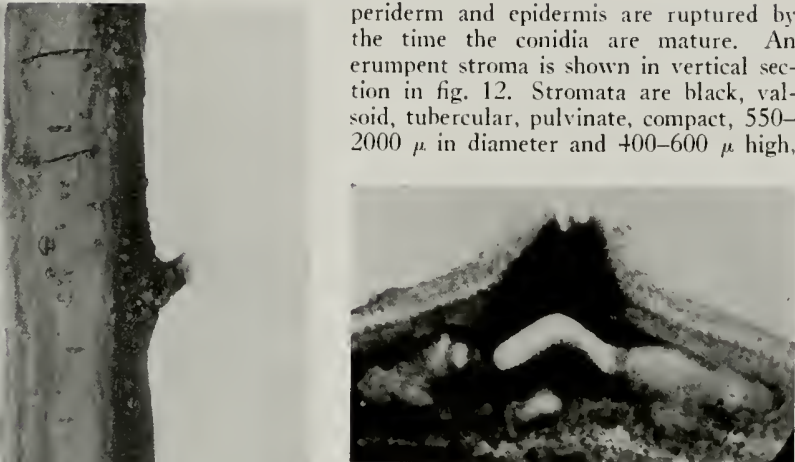

Fig. 12.-Portion of a stroma of Cytospora. The erumpent appearance of the stroma is shown in vertical section. The black stromatic tissue with its locules and spores is embedded in the cankerous host tissue. $X 55$.

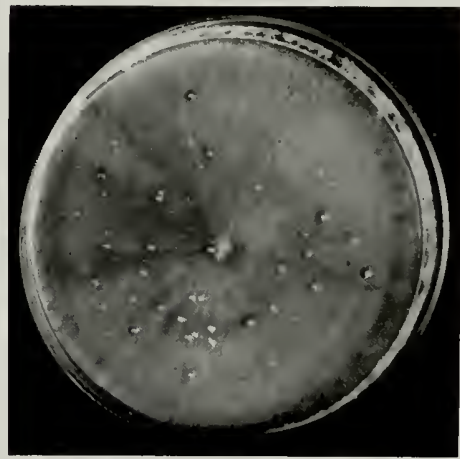

Fig. 13.-Culture of Cytospora on corn meal agar. The black stromata are embedded in white to greenish-white tufts of hyphae.

and they are exposed through the ruptured lost tissues. The locules are irregularly arranged. The conidia are continuous, hyaline, allantoid, elongate, $4.5-9 \times 1-t$ $\mu$, and they exude from the stromata in cirrhi. Conidiophores are typically simple but occasionally are branched.

A culture of Cytospora, grown on corn meal agar, is shown in fig. 13. The fungus, in its early development, appears white color of the living and diseased bark and by the shrunken appearance of the diseased bark. $X 1$.

Fig. 11. - Cytospora canker and dieback on black oak. Only a few scattered, erumpent stromata are present in the light to dark brown, sunken, diseased region. The border of this 
with a very sparse growth of interwoven mycelium. Later a more dense growth of white surface and aerial mycelium derelops. Tufts of hyphae appear more or less concentrically or promiscuously interspersed with the mycelium. They are white to greenish white above and green below. In some instances the hyphae adjacent to the developing tufts are light brown. The stromata are black, firm, multilocular, tubercular, 525-1600 $\mu$ in diameter, 600$1500 \mu$ high and embedded in tufts of hyphae. The conidia produced in culture are 3-9 $\times 1-3.5 \mu$. Except for greater variability in size, they are identical with the conidia produced in the host tissue. The conidiophores are simple to branched, $10-15 \times 2-3.5 \mu$, and hyaline.

This fungus is considered to be Cytospora intermedia Sacc. (Yalsa intermedia Nits.). The pycnidial stage is identical morphologically with that of Jaap's Fungi Selecti No. 621 Valsa intermedia Nits. (Cytospora intermedia Sacc.).

\section{Nummularia Canker and Dieback}

Small to large Nummularia cankers were found on branches of red oaks. The cankers extend a few inches to several feet along the branches; dieback results when the branches are completely girdled by the cankers. The cankers appear as sunken diseased regions with small to large stromata located at irregular intervals. The smooth, reddish-brown, cankerous bark and two stromata in a portion of a canker are shown in fig. 1t. On old branches the bark turns black and becomes fissured. The fissures are produced by lengthwise and crosswise splitting of the bark. The borders of the cankers are sharply defined on young branches by a contrast in color between living and cankerous tissues. There is no discolored streaking in the wood; however, the wood appears dried out and light brown.

Nummularia stromata produced in the cankerous tissue are shown in fig. 14. These stromata are discoid to linear, suheffuse and rather thick. Immature stromata are covered with a pulverulent, cinereous, conidial hymenium that sloughs off at maturity, when the stromata become black, carbonous, rigid, bare and usually somewhat convex. They are laid down in the phellem immediately under the epidermis, and the epidermis disappears during the early development of the stromata. The periderm, endodermis, pericycle and phloem tissues turn dark brown to black and disintegrate. The cortical tissue is crushed during the development of the st romata.

The stromata vary from +60 to $530 \mu$ thick. The perithecia, shown in fig. 15 . are large, monostichous, globose to ovoid, and immersed in the stroma. They range from 260 to $400 \mu$ in diameter and from 350 to $370 \mu$ in height. The height measurement does not include the extended ostioles, which are 135-200 $\mu$ long and 18$30 \mu$ in diameter. The asci are cylindric, 90-125 $\times 9.12 \mu$, pedicellate and 8spored. The ascospores are arranged obliquely in one row in the ascus and are ellipsoid to fusiform, continuous, 15-19 $\times$ 9-12 $\mu$, and brown when mature. They are illustrated in fig. 16. The paraphyses are hyaline, $125-215 \times+.7-7.8 \mu$, filiform and somewhat abundant.

This Nummularia was determined as

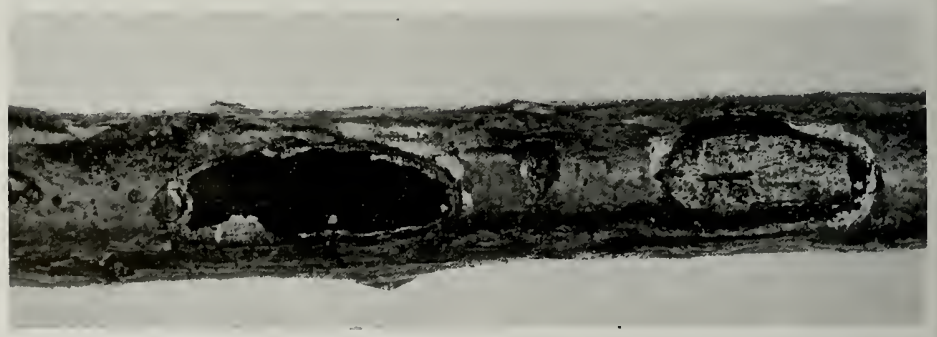

Fig. 14.- Portion of a Nummularia canker on red oak. The gray to blackstromata develop in the smooth, reddish-brown cankerous tissues. $\mathrm{X} 11 / 2$. 
Nummularia clypeus (Schw.) Cke. by Dr. IV. IV. Diehl.

Single-spore plantings of Nummularia clypeus, from red oak, were made on corn meal agar. Abundant germination of ascospores occurred in 12 hours. The ascospores germinated by sending out, terminally or laterally, one to several germ tubes from each spore. Branching of the

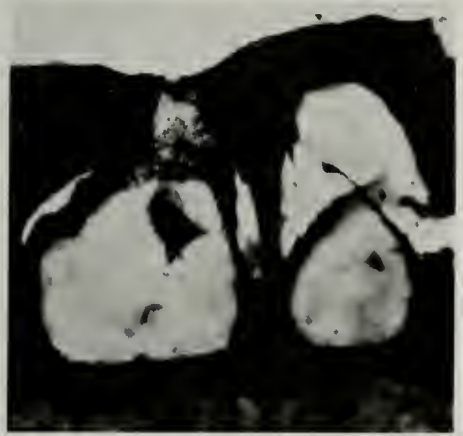

Fig. 15.-Portion of a stroma of $\mathrm{N} u m m u-$ laria in vertical section. The ovoid perithecia are cmbedded in the black stromatic tissue, and the black perithecial wall separates readily from the stromatic tissue. X 70 .

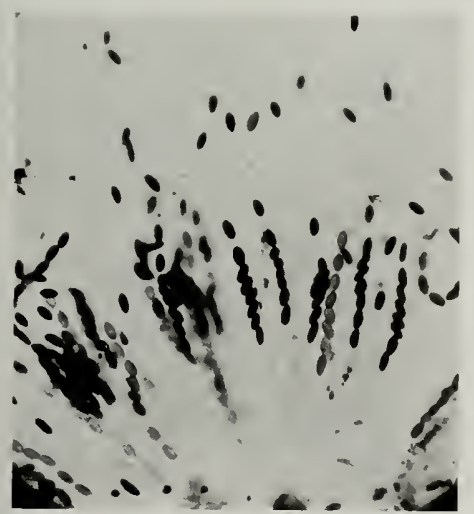

Fig. 16. Ascospores of Nummularia. The immature ascospores are hyaline to light brown, and the mature ascospores are dark hrown to black. Eight ascospores derelop in each hvaline ascus. I 200. germ tubes occurred in $2+$ hours and after they were $60 \mu$ long. One colony, which had grown from a single spore, produced in 10 days a growth $80 \mathrm{~mm}$. in diameter. The average growth for several colonies was $36 \mathrm{~mm}$. in diameter, produced in 5 days. Cultures of $\mathrm{N}$. clypeus from singlespore plantings on corn meal agar developed a sparse growth of interwoven, gray aerial hyphae. The surface growth was interwoven, gray-tan and more dense than the aerial growth. Spores placed in sterile distilled water gave an average germination of 28 per cent in 17 lours. $\mathrm{X}$. clypeus failed to sporulate when grown on artificial media. A culture of this Nummularia is shown in fig. 17.

A fungus isolated from 28 specinens of diseased oak appeared to he identical with

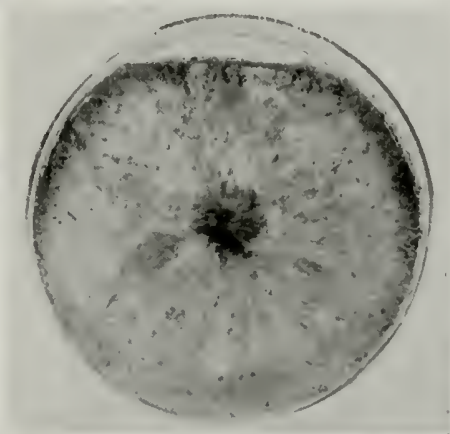

Fig. 17.-Culture of Nummularia grown from a single-spore isolate. The aerial hyphae are gray, and the surface hyphae are gral to tan. The fungus grows vigorousiy and spreads rapidly on corn meal agar.

known cultures of Vummularia clypeus. This fungus was isolated from discolored wood, stromatic tissue of cankers, cankerous bark and discolored regions of living wood of hoth red and shingle oak.

\section{Diatrype Canker and Dieback}

Diatrype cankers were found on medium to small branches of red oak in the northeastern region of 1 llinois. A young canker is shown in fig. 18 and an old canker in fig. 19. Diatrype canker develops as a light to dark reddish-brown, 


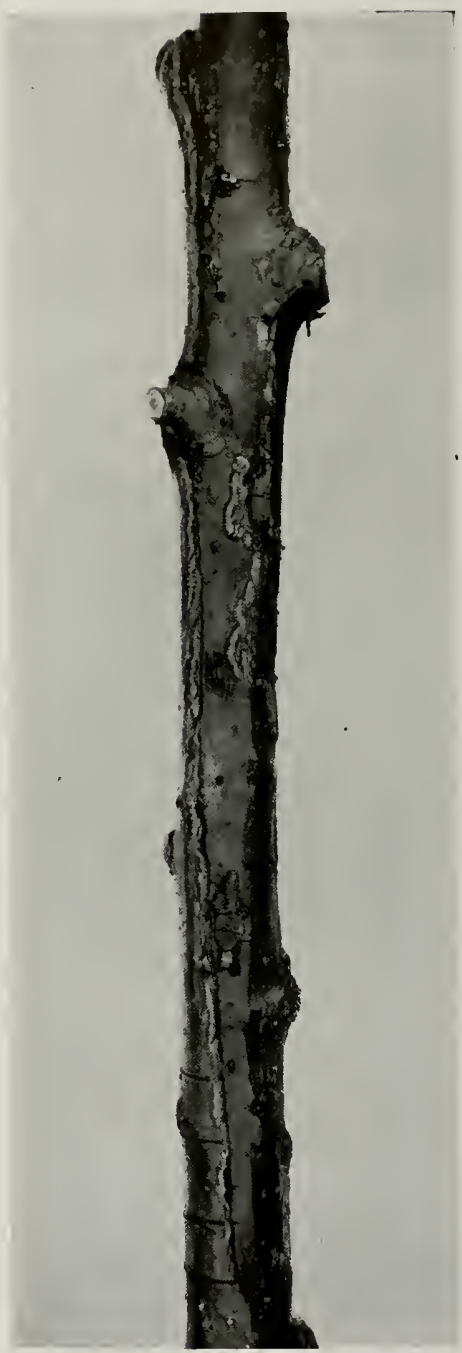

Fig. 18.-Diatrype canker and dieback on red oak. The diseased tissue is light to dark reddish brown and sunken. The border of the diseased region is raised where living and dead tissues meet. The stromata are irregular, black, erumpent, roughened and fissured. $\mathrm{X} 1 / 2$.

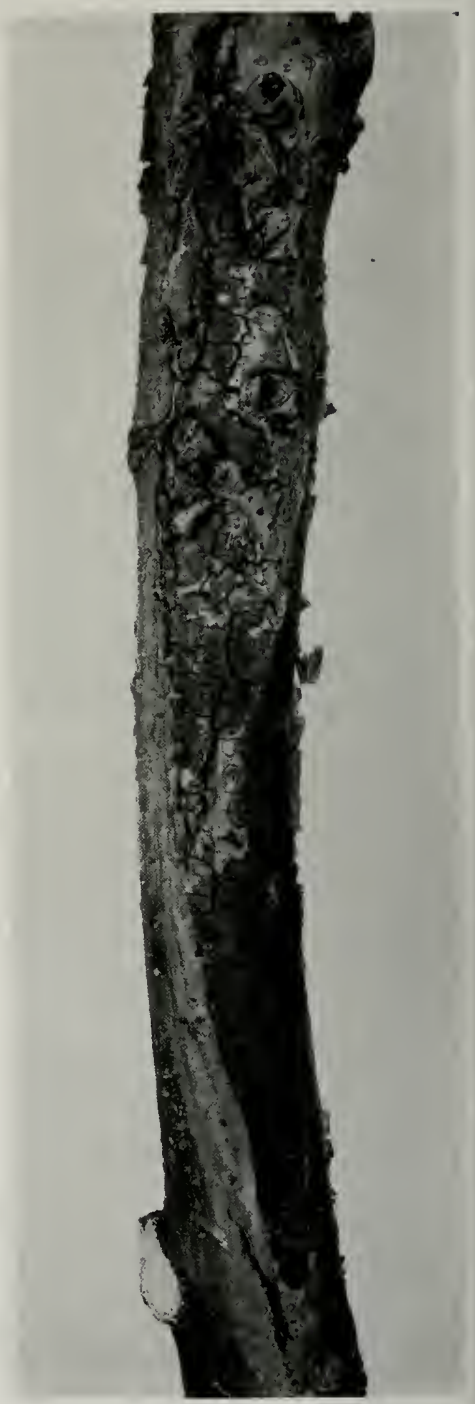

Fig. 19.-Diatrype canker on red oak. Portion of an old canker which shows a large, fissured, mature stroma that has almost covered the whole cankered region. $\mathrm{X} 1 / 4$. 


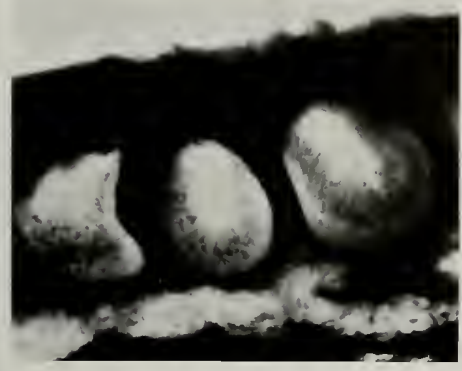

Fig. 20. Perithecia of Dialrype. A vertical section of stromatic tissue which shows the arrangement of perithecia. $\$$ is.

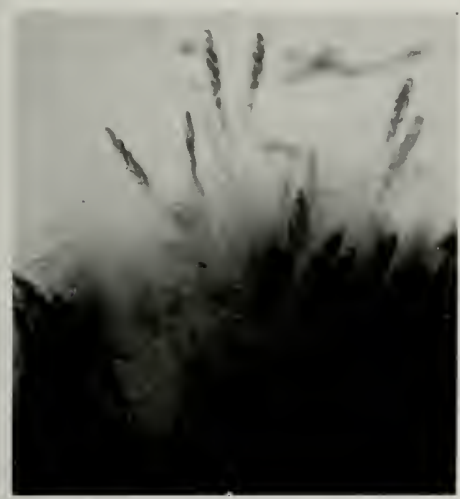

Fig. 21. -Asci and ascospores of Dialrype. Each hyaline and clavate ascus contains hyaline, botuliform, 1-celled ascospores. I 320 .

sunken region on the branch. The canker is conspicuous because of the contrast between the healthy and the diseased tissues, and it is surrounded by a callus. Dieback develops when the branches are completely: girdled by cankers.

The stromata of Diatrype develop subepidermally, and they become erumpent at maturity. A portion of a stroma is shown in fig. 20. Stromata are diatrypoid, black and smooth at first, but later they become grayish black, somewhat roughened and fissured. The fissures are produced by vertical and longitudinal splitting of the stromatic tissue. The ovoid, dark, car- honous and ostiolate perithecia are shown in fig. 20. Immature perithecia are $48-53$ $\mu$ in diameter and 63-68 $\mu$ high. Mature perithecia are globose and 200-225 $\mu$ in diameter without their extruded beaks. which are 75-85 $\mu$ long from the top of the perithecia to the ostioles at the external surface of the stromata. The ostioles are papillate, round, not compressed, and are $30-40 \mu$ in diameter. The asci, shown in fig. 21 , are 8 -spored, hyaline, $30-33.5 \times$ $4.8-5.2 \mu$, and somewhat clavate with a tapering base. Each ascus has a pore at its apex. The ascospores are pictured in fig. 21. They are hyaline, $6.6-9.5 \times 1.6-3.3$ $\mu$, botuliform and continuous. Known cultures of Diatrype were not secured on artificial media.

Our material agrees with Diatrype stigma (Hoffm.) Fr. as represented in Ellis \& Everhart's North American Fungi, Second Series, No. 3,529.

\section{Phomopsis Canker and Dieback}

Phomopsis canker and dieback, identified by isolation of the fungus from the diseased wood, was found on branches of pin, red, swamp white and white oaks. Externally, Phomopsis cankers are reddish brown, elongate, smooth and somewhat shrunken, and they have definite borders where the cankerous and living bark meet. In most of the cankers the diseased xylem tissue varies from light brown to dark brown; and occasionally light to dark brown streaks extend into the adjacent living xylem tissue.

Phomopsis was found fruiting in the diseased bark of only one canker and dieback specimen of oak-pin oak. The pyonidia in the diseased bark are black, ovoid to discoid, erumpent, 200-270 $\mu$ high and $+00-470 \mu$ in diameter. They are fundamentally laid down in the phellegen-phelloderm region of the bark. Their development causes very little distortion of the underlying cortical tissue, but the overlying phellem and epidermis are ruptured by the enlarging pricnidia. The ruptured tissues form a triangular-shaped shield around the mature pycnidia. The conidia, $\alpha$-spores, are hyaline, $7-10 \times$ $1.5-3 \mu$, ellipsoid to fusoid, and continuous.

In culture, Phomopsis develops a sparse growth of gray mycelium that spreads rapidly on corn meal agar. Pycnidia are 
promiscuously interspersed with the mycelium. The portion of the pycnidium that grows above the agar is gray, and the portion that is embedded in the agar is black.

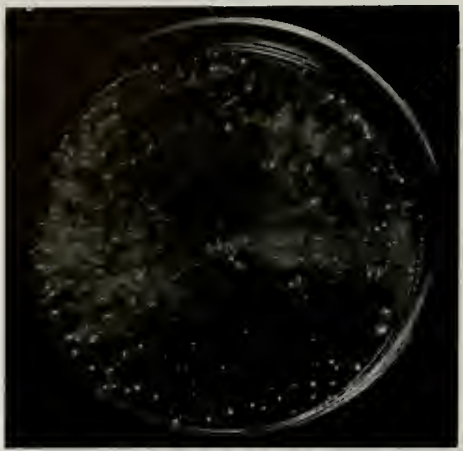

Fig. 22. - Culture of Phomopsis on corn meal agar. The gray pycnidia are produced promiscuously and are interspersed with the mycelium.

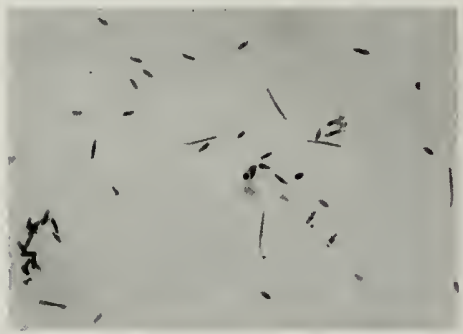

Fig. 23. Spores of Phomopsis. Both $\alpha$ and $\beta$-spores are produced on sterilized red oak twigs. The ellipsoid to fusoid, continuous, hyaline $\alpha$-spores are produced in greater abundance than are the straight to curved or hamate, filiform, hyaline $\beta$-spores. I 300 .

A culture of Phomopsis on corn meal agar is shown in fig. 22.

Phomopsis from the red and swamp white oak branches produced both $\alpha$ - and $\beta$-spores in culture. It was isolated from the discolored, diseased xylem and from the living xylem of cankers that showed fine, light to dark brown streaks. It was cultured not only from cankers but from the black, discolored xylem tissue of a dieback specimen of red oak. One canker from which Phomopsis was cultured had stromata of Diatrype stigma on the cankerous tissue.

The pycnidia of the Phomopsis that produced both $\alpha$ - and $\beta$-spores are black, globoid to ovoid, without ostioles, are subcarbonous, and $500-1000 \mu$ in diameter. The $\alpha$ - and $\beta$-spores are shown in fig. 23. 'The $\alpha$-spores are elliptic to fusoid, $5-10 \times 2-+$ $\mu$, hyaline and continuous. The $\beta$-spores are straight to curved or hamate, normally $16-30 \times 1-2.8 \mu$, filiform, hyaline and continuous. In one instance the $\beta$-spores measured $28-3+\times 3-5 \mu$.

Our material from the red and swamp white oak branches agrees with Phomopsis quercina (Sacc.) v. Höhn. as represented in Sydow's Mycotheca germanica No. 1,122 .

Phomopsis grown from the branch cankers of pin oak and white oak and also from the blighted petioles of one specimen of red oak produced only $a$-spores in culture. The pycnidia are black, $400-500 \times 330$ $+50 \mu$, globoid to ovoid, and pseudoparenchymatous. The conidia are continuous, $+-10 \times 2-4 \mu$, hyaline, and ellipsoid to fusoid. They are comparable in size to the Phomopsis spores produced in the cankerous tissue of the pin oak and also to the $a$-spores of Phomopsis grown in culture from red and swamp white oak branches.

\section{CANKER DISEASES}

\section{Phoma Canker}

Phoma cankers were found on twigs and on small to large branches of bur, pin, red, shingle and white oaks. The cankers are dark brown to black, somewhat shrunken and roughened, and have definite borders where the cankerous and living tissues meet. In some specimens of diseased oak, dark brown to black streaks of discoloration are present in the living wood beyond the extremities of the cankers. 'This discoloration is similar to that of the Dothiorella cankers shown in fig. 3. Pycnidia develop in the phellogen-phelloderm region. The overlying host tissue is ruptured by the developing pycnidia, which are erumpent at maturity.

Five Phoma cankers-two on twigs, two on small branches and one on the trunk of a small tree-were found on red oak. The pycnidia in these cankers are 
black, globoid to slightly ovoid, ostiolate, and $150-200 \mu$ in diameter. The conidia are hyaline, $3-3.5 \times 1-2.5 \mu$, oblong to fusoid, and continuous.

From one of the two twig cankers, Phom was obtained in culture; Cephalosporium was obtained from the other. Dothiorella was obtained from the trunk canker and from one branch canker; Penicillium and Cephalosporium were obtained from the other branch canker. The Phoma from the twig canker, cultured on corn meal agar, produced black, globose pycnidia $80-110 \mu$ in diameter. The conidia are oblong to fusoid, hyaline, $3.3-3.6 \times$ $2.5-3.2 \mu$, and continuous.

Phoma was obtained in culture from 22 canker specimens of diseased oak that had no Phoma pycnidia in the cankerous tissue. ( )ne of these cankers was on bur oak, 2 on pin oak, 12 on red vak, 1 on shingle oak and 6 on white oak. Phoma was grown from the living wood that showed dark brown to black streaks in 7 of these 22 specimens and from the cankerous tissue of the remaining specimens.

Phoma was the only fungus obtained in culture from 17 of the 22 diseased oak specimens mentioned above. It was obtained in association with other fungi from the remaining 5 specimens. The associated fungi were Alternaria, Cephalosporium and Dothiorella. Coryneum was found fruiting on 1 and Cytospora on 2 of the 22 specimens.

Cultures of Phoma from the above-described sources produced pycnidia on corn meal agar. The pycnidia, illustrated in fig. 2t, are black, globoid, pseudoparenchymatous, and $50-200 \mu$ in diameter. Conidia are lyaline, $1.5-+\times 0.7-2.5 \mu$, continuous, and oblong to fusoid. The fungus produces a dense growth of radiate mycelium, which develops slowly. Black pycnidia are interspersed with the mycelium. A culture of $P$ hom $n$ is shown in fig. 25. 'The dense growth of surface hyphac is tan to brown with a $1 \mathrm{~mm}$. marginal growth of white hyphae. The sparse growth of aerial lyphae is white to gray.

All of the pycnidia and conidia of $P / h o m a$ described above are sufficiently similar in size and shape to be regarded as from one species. This species compares more closely with the morphological description of Phoma aposphaerioides Briard \& Hariot (Saccardo 1892) than with the morpho- logical descriptions of other species of Phoma on Quercus.

A second Phoma was found fruiting on the blighted petioles of a post oak. This

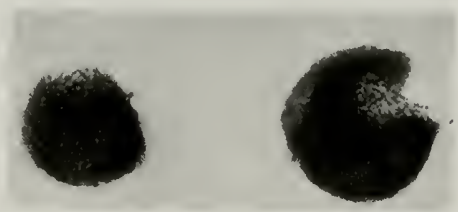

Fig. 24. Pycnidia of Phoma. Numcrous black, globoid, pseudoparenchymatous pycnidia are produced on corn meal agar. X 140 .

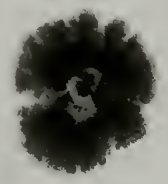

Fig. 25.- Culture of Phoma on corn meal agar. Numerous black pycnidia develop in more or less concentric circles.

fungus was grown in culture from these diseased petioles and from blighted petioles of another post oak.

On the petioles, the second Phoma produced dark brown to black, ovoid, pseudoparenchymatous pycnidia $350-+50 \mu$ in diameter. The conidia are hyaline, $6-8.5$ $\times 2.8-3 .+\mu$, continuous, and ellipsoid to fusoid. On corn meal agar the fungus produced dark brown to black, ovoid, pseudoparenchymatous pycnidia $250-+00 \mu$ in diameter, and conidia that are hyaline, $6-9 \times 1.5-3 \mu$, and oblong to fusoid.

This Phoma was associated with only the blighted petioles of twig blight specimens of oak. In this disease the leaves wilt and then turn brown to reddish brown during the summer (July and 
August). The petioles, externally and internally, turn brownish purple, and the twig tips die back 1 to several inches. The bark turns brown and then dries and shrinks tightly around the wood.

This second Phoma agrees with the morphological description of Phoma quercina (Peck) Sacc. (Saccardo 188t).

\section{Fusicoccum Canker}

Fusicoccum cankers, shown in figs. 26 and 27, are slightly sunken, dark brown to brownish-black areas, with conspicuous borders where the cankerous and living tissues meet. Erumpent stromata develop in the cankerous tissue. Deep fissures, which extend partially to completely across the cankerous bark, are very conspicuous. Dark brown discoloration of the wood beneath the cankerous bark does not extend into the living wood beyond the margin of the canker. Fusicoccum was isolated from two cankers on red oak and from brownishpurple, blighted petioles of two diseased oaks (black and post oaks). The brownish-purple discoloration is most apparent at the base of the petioles; it fades to a light brown color where the petioles and the brown leaf blades unite. Abscission layers are formed at the junction of the petioles and twigs, and the leaves are easily removed from the twigs.

Stromata are laid down fundamentally in the phellogen-phelloderm region of the bark. Their development causes very little distortion and crushing of the underlying cortical cells. The overlying phellem and epidermis are ruptured as the stromata enlarge and mature. The mature stromata appear dotlike in the cankerous tissue.

'The stromata, 700-1400 $\mu$ in diameter and $250-450 \mu$ high, are black, ovoid to conoid, erumpent, multilocular and with a sterile central region of pseudoparenchymatous hyphae. A vertical section of a stroma is shown in fig. 28 . The conidial cavities are ovoid to elongate and somewhat irregular in outline. Conidia, shown in fig. 29 , are hyaline, $6-12 \times 2-4 \mu$, ellipsoid to fusoid, and continuous. Conidiophores are hyaline to subhyaline, 6-12 $\times 1.5-3 \mu$, and bacillar.

Fusicoccum produces white mycelium on corn meal agar. A few promiscuously scattered stromata that are black, 1300 $1500 \mu$ across, ovoid to globoid, and multi-

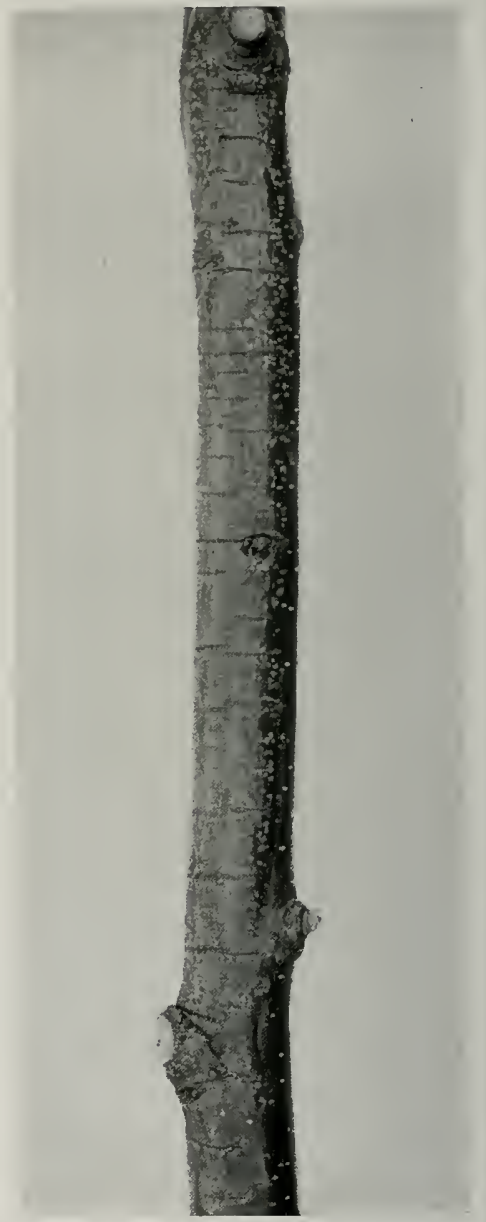

Fig. 26.-Fusicoccum canker on red oak. The shrunken, dark brown to brownish-black, cankerous tissue contains numerous black, ovoid to conoid, erumpent stromata. Numerous fissures extend partially to completely across the cankered region. $\mathrm{X} 1$.

locular are interspersed among the hyphae. The pycnidial locules are globoid to ovoid, black, and $650-800 \mu$ in diameter. 'The conidia are hyaline, $6-13 \times 2.5-4 \mu$, con- 


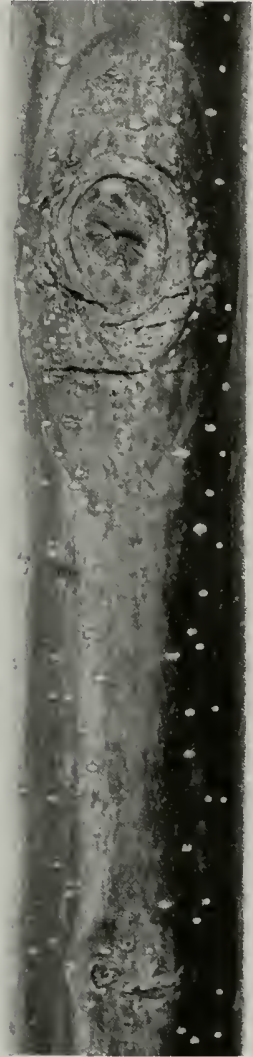

Fig. 27. liusicocum cankers on red oak. The erumpent stromata and fissures in the shrunken, cankerous bark are conspicuous in the larger canker, which has developed around the base of a twig. 'The smaller canker, below, has developed from infection through an injury. I 3 .

tinuous, and they are ellipsoid to fusoid.

Our material agrees with Fusicoccum quercinum Ell. \& $\mathrm{Ev}_{\mathrm{V}}$. as represented in North American Fungi, Second Series, No. 3,360. Saccardo (1899) considered $F$. quercinum Ell. \& Ev, identical with $F$. Ellisianum Sacc. \& Syd. and not with $F$. quercinum Sace. (Saccardo 1S84). Therefore, according to the classification of Sac-

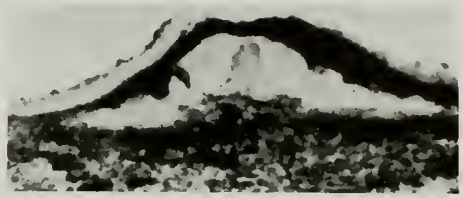

Fig. 28. Portion of a stroma of Fusicoccum from red oak. This vertical section shows the internal cavity of the stroma and the black stromatic tissue that has pushed through the host tissue. I 58 .

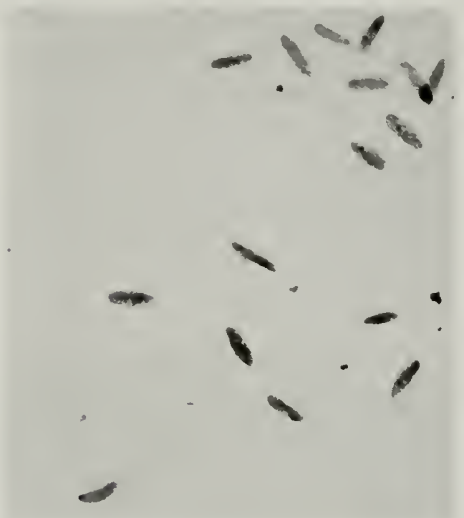

Fig. 29.- Spores of Fusicoccum. The spores are hyaline, cllipsoid to fusoid, and continu ous. I 320 .

cardo (1899), the material that we studied is $t$. Lllisianum Sace. \& Syd.

\section{Sphaeropsis Canker}

A portion of the only Sphaeropsis canker found on oak, on a red oak twig, is shown in tig. 30. This canker is reddish brown, is promiscuonsly dotted with Sphaeropsis pycnidia and is bounded by a definite border made conspicuous by the contrast between the smooth, reddish-brown, dead hark of the canker and the adjacent, living, dark green bark. The dead wood beneath the cankerous bark is discolored chocolate brown and is bordered by a black region adjacent to the healthy wood. This discoloration in the wood extends down the twig approximately 1 inch heyond the base of the cankerous bark. 
The pycnidia are black, ostiolate, separate to cespitose, globose to ovoid, $650-$ $860 \mu$ in diameter and $400-600 \mu$ high. They arise fundamentally in the phellogenphelloderm region of the hark. The over- lying phellem and epidermis are broken when the pyenidia mature and become erumpent, and there is very little crushing or disintegration of the underlying tissues. The broken host tissues form oval to cir-

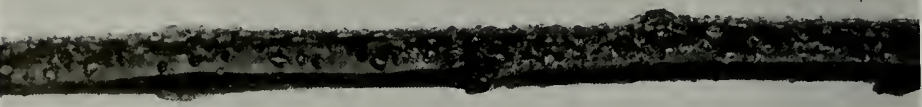

Fig. 30.- Portion of a Sphaeropsis canker on red oak. The reddish-brown, smooth, shrunken cankerous tissue contains numerous black, globose to ovoid, erumpent pycnidia. $\mathbf{X} 1$.

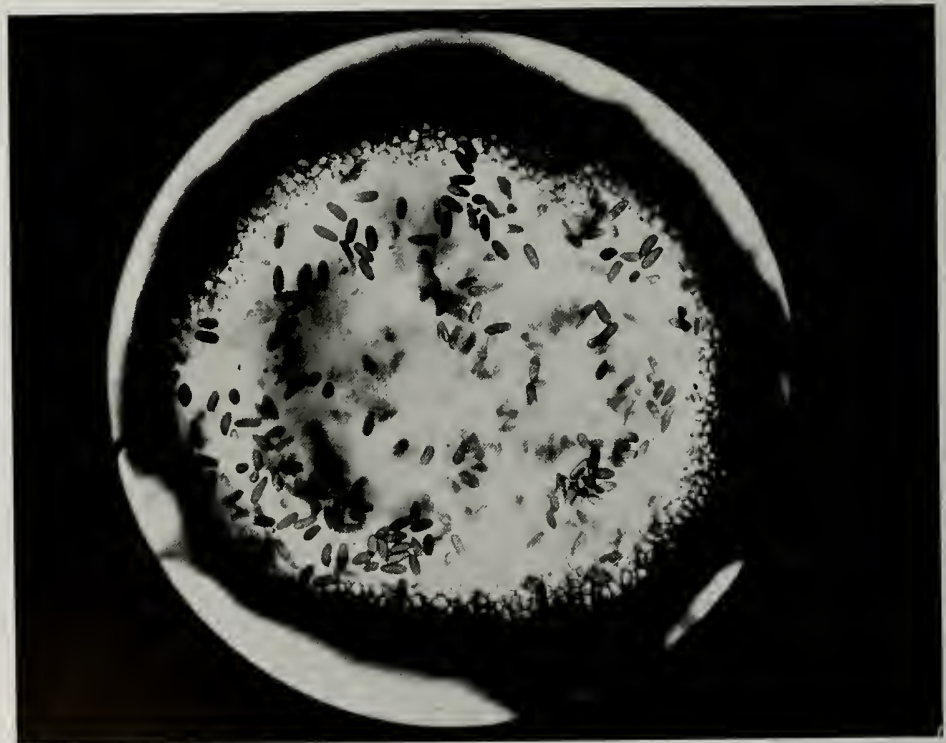

Fig. 31.- Spores of Sphaeropsis. A cross section of a pycnidium which shows the brown, 1-celled, ovoid to ellipsoid spores and the black pseudoparenchymatous pycnidial tissue. X 150 . 
cular shields around the erumpent pycnidia. The conidia, shown in the cross section of a pronidium in fig. 31, are hrown, 15-25 × $8-11 \mu$, continuous, and ovoid to ellipsoid. The conidiophores are hyaline, rodlike, $6-9 \times 1.5-2.5 \mu$, and the oval ostioles are $15-25 \mu$ in diameter. This fungus was not grown in culture.

Our material compares closely with the morphological description of Sphaeropsis quercinum Cke. \& Harkn. (Cooke \& Harkness 185t).

\section{Bulgaria Canker}

Apothecia were obtained from Bulgaria cankers on two hlack oak trees. The cankers were located on the trunks ap-

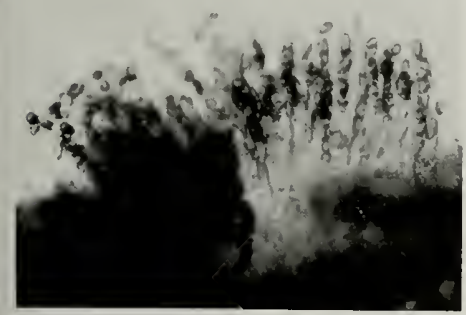

Fig. 32. Ascospores of Bulgaria. H.ach hyaline, cylindric, pedicillate ascus contains + to 8 brown, ovoid to suboblong, continuous ascospores. \. 2.30 .

proximately 2 feet above the soil line. small and oxal to large and irregular areas of the bark had been killed. The camb.um under the dead bark was tan to light brown and was water soaked. Black zone lines were present in the underlying x)lem tissue. Killing of the cambial region was followed by general decline and timally death of the infected trees.

Several attempts to grow the fungus on artificial media (corn meal agar, potato dextrose agar and acidified potato dextruse agar) from ascospores and from apothecial tissue were unsuccessful. Ispergillus, Cephalosporium, Fusarium and an unidentified fungus were obtained in culture from the apothecial tissue of $\mathrm{Bul}$ garia.

The apothecia of Bulgaria are black, substipitate to sessile, gelatinous to Heshy; and cupulate with a wall $700-1800 \mu$ thick. Asci are hyaline, $f(1)-60 \times 6-10$ $\mu$, cylindric, pedicillate and $t$ - to 8 -spored. The ascopores, fig. 32, are brown, $7-15 \times$ $+-0.5 \mu$, continuous, and ovoid to ellipsoid or suboblong. Paraphyses are subhyaline to light tan, $75-110 \times 0.7-1.7$ $\mu$, and filiform.

Our material agrees with Bulgaria inquimans (Pers.) Fr. as represented in Ellis' North American Fungi No. +48 .

\section{DIEBACK DISEASES}

\section{Coniothyrium Dieback}

Coniothyrium branch and twig dieback was found on hlack, bur, pin, red, swamp white and white oaks. The Coniothyrium fungus was isolated from diseased bark, blighted twigs and discolored regions in the live wood that extended from the dead wood in specimens of dieback.

In this type of dieback the diseased bark is light reddish brown to dark brown. smooth, slightly raised, and continuous with the surrounding living bark. There are no pronidia or fissures in the diseased bark. In some cases streaks that are light to dark brown and fine to broad extend from the discolored dead wood beneat'. the diseased bark into the living wood below the dieback region.

On corn meal agar, the Coniothyrium isolated from oak develops dark tan to

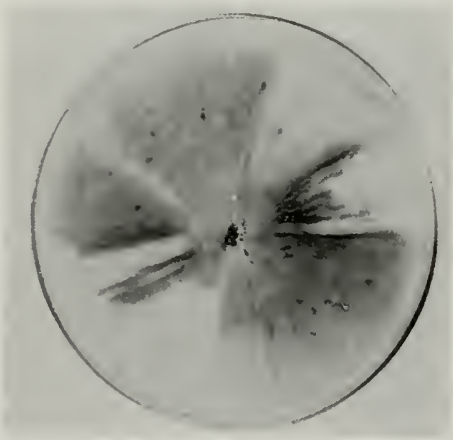

Fis. 33. - Culture of Coniorlyrium on corn meal agar. The dark brown to black, partially submerged, sphaeroid pycnidia develop in old cultures. 
brown mycelium, fig. 33 . The mycelium is white when young but hecomes $\tan$ to brown with age. A dense growth of surface hyphae and a very sparse growth of aerial hyphae develop in culture.

Pycnidia develop as partially submerged, dark brown to black, pseudoparenchyma-

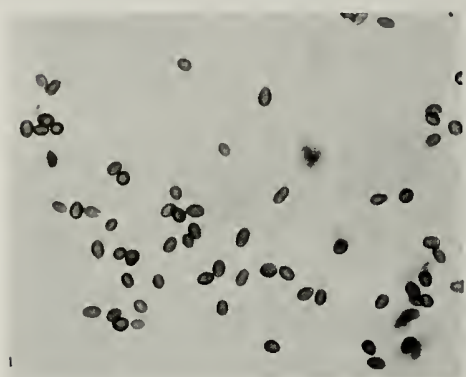

Fig. 34.-Spores of Coniothyrium. They are ovoid to subcylindric, olivaceous and 1celled. X 430 .

tous, spheroidal structures with flattened bases; they are $150-500 \mu$ in diameter. The conidia, fig. 34 , are ovoid to subcylindric, $+7 \times 3-4.5 \mu$, olivaceous and continuous.

This Coniothyrium compares closely with the morphological description of Coniothyrium truncisedum Vestergr. (Saccardo 1899).

\section{Pyrenochaeta Dieback}

Pyrenochaeta dieback was found on pin oak and white oak. The diseased bark is dark brown to brownish black and is shrunken; most of it is smooth. Fungous fructifications are not present in the cankerous tissue. The underlying wood is dark brown to black and has broad streaks of discoloration that extend into the living wood. Pyrenochaeia was isolated from discolored living wood of pin oak and white oak about one-half inch below the base of the dieback regions; also from one twig blight specimen of white oak.

On corn meal agar the fungus produces small, globose to ovoid, pseudoparenchymatous, dark brown to black, ostiolate pycnidia, normally $60-100 \mu$ in diameter, and with setae. The measurement of the pycnidia of one culture from white oak is $335-535 \mu$ in diameter and, in a second culture, $100-250 \mu$ in diameter. Two pycnidia are shown in fig. 35 . The ostioles are circular and $8-10 \mu$ in diameter. The setae, shown in fig. 35, are brown, septate, $10-50 \times 2-+\mu$, straight to curved, and tapering toward the apices. Conidia of this Pyrenochaeta are very small, hyaline, $1.5-4 \times 0.7-3 \mu$, fusiform, continuous, and they are ovoid to ellipsoid in shape.

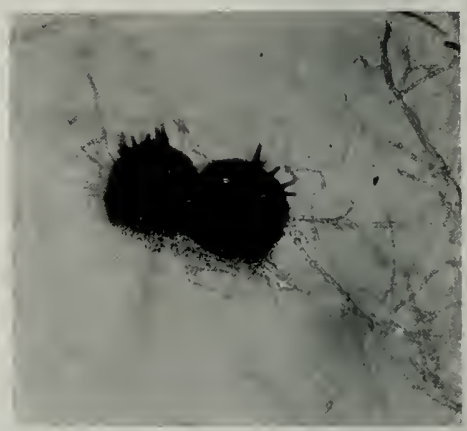

Fig. 35.-Pycnidia and spores of Pyrenochata. The small, globose to ovoid, dark brown to black pycnidia have septate, straight to curved, tapering, brown setae especially around their ostioles. The spores are minute, hyaline, continuous, fusiform and ovoid to ellipsoid. X 170.

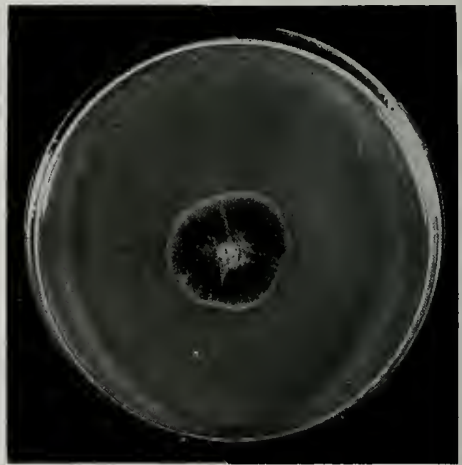

Fig, 36.- Culture of Pyrenochaeta. The tan to dark brown mycelium grows slowly and produces a dense mat on corn meal agar. 
The mycelium is light to dark brown. A culture is shown in fig. 36 . The sparse growth of aerial hyphae is gray to light brown. The dense growth of surface and subsurface hyphae is light to dark brown with a $1 \mathrm{~mm}$. marginal growth of white hyphae.

This Pyrenochaeta does not appear to compare morphologically with any of the described species of Pyrenochaeta.

\section{Pyrenochaeta minuta sp. nov.}

Mycelium in culture light to dark brown in mass, with sparse, gray to light brown aerial hyphae and abundant light to dark brown surface hyphae; pycnidia scattered, globose to ovoid, sooty brown to black, $60-535 \mu$, mostly $60-100 \mu$, in diameter; ostioles round, $8-10 \mu$ in diameter; setae brown, septate, straight to curved, tapering toward apex, $10-50 \times$ $2-t \mu$; conidia hyaline, minute, fusiform. continuous, ovoid to ellipsoid, $1.5-4 x$ $0.7-3 \mu$.

Mycelio in cultura diluto usque atrato brunneo in massa, hyphis aeriis sparsis griseis usque dilutis brunneis, hyphis in superficie medii abundantibus dilutis usque atratis brunneis, picnidis sparsis globosis usque ovoideis fuliginosis usque nigris $60-535 \mu$ ue plurinum $60-160 \mu$ diametris cum ostiolis rotundatis $8-10 \mu$ diametris et setis brunneis septatis rectis usque curvatis ad apicem attenuatis $10-50 \times 2-4 \mu$, conidiis hyalinis minutis fusiformibus continuis ovoideis usque ellipsoide is $1.5-1 \times 0.7-3 \mu$.

Tipe specimen: Pure culture isolated from the cortical parts of an infected branch of Quercus palustris . Muench., collected by J. C. Carter at Xenia, Clay Countr, Illinois, October S, 1937, Ill. Nat. Hist. Surv. Acc. No. 27,082.

Other specimens cultured from branch of Quercus alba L. collected by J. C. Carter at Galena, Jo Daviess County, Illinois, Octoher 28, 1937; twig of $Q$. alba collected by J. C. Carter at Lake Forest. Lake County. Illinois, September 25. 1937.

\section{ROOT ROT}

\section{Armillaria Root Rot}

Ohservations were made in the course of this investigation to deternine the cause of staghead, general dieback and the sudden dying of numerous oak trees. These pathologic conditions of oak were observed in widely scattered sections of Illinois; however, they were noticed especially in the northeastern section of the state. In nearly every instance, staghead and general decline of oak were associated with root disturbances, especially with root rot.

In the stagheaded trees examined, young roots and the white wood of older roots

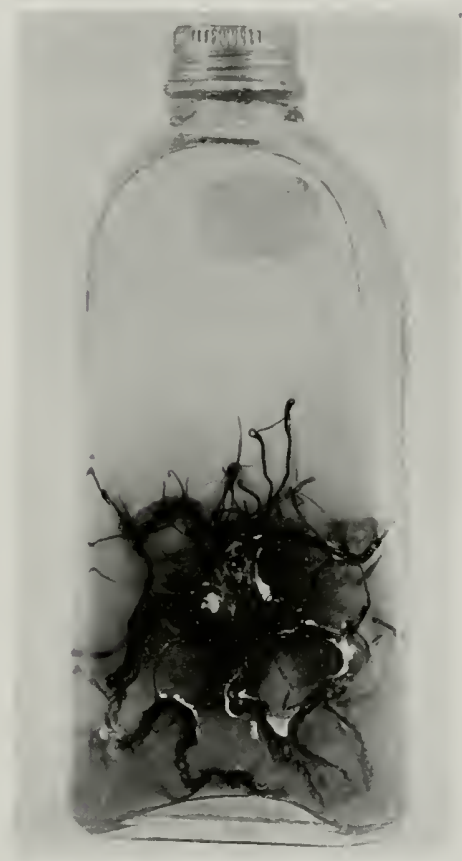

Fig. 37.- Culture of Armillaria. The reddish-brown rhizomorphs are produced in abundance on corn meal agar.

were affected by a white rot. The brown wood of the older roots showed a gradual change from the early to the late stages of rot. In the early stage of rot the brown wood of the older roots hecomes lighter hrown, but later it gradually changes to gray, which is sometimes mottled. Finally: in the late stage of rot, the wood become: white, soft and spongy, and in time it crumbles away and leaves a cavity in each infected root. From specimens of this 


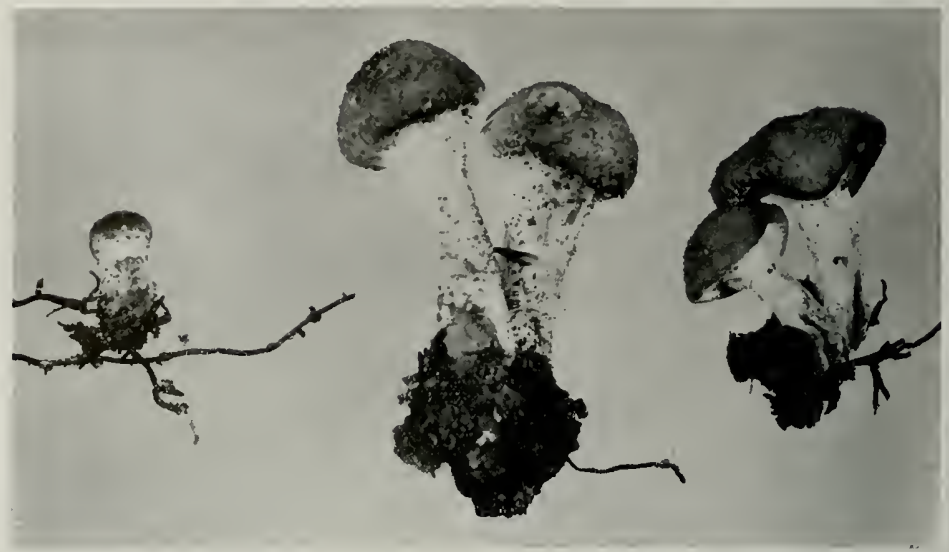

Fig. 38.- Young sporophores of Armillaria. They were found developing in the soil about 1 foot from the base of a bur oak tree and above the infected root. The reddish-brown to black rhizomorphs are attached to the young sporophores. $\mathrm{X} 1$.

white, heart-rot wood as well as from rhizomorphs, Armillaria mellea (Vahl.) Quél. was isolated. A culture of A. mellea with rhizomorphs that permeate the potato dextrose agar is shown in fig. 37 .

In the roots of many of the diseased oaks, rhizomorphs of Armillaria, shown with attached sporophores in fig. 38, develop in the cambial region and in root cavities. In the late stage of staghead, the rhizomorphs are frequently found under the bark at the base of the large roots and in the root crotches. Rhizomorphs may enter through wounds in the root crotches at or below the surface of the soil. They are present in the duff at the base of seriously infected trees and frequently are found spreading through the soil for distances of 25 feet or more. In the carly stage of staghead, rhizomorphs are associated with the death and rotting of the very small feeding roots. Gradual destruction of these roots reduces the feeding capacity of the root system and limits the amount of foliage that can be supplied with plant food and water. An inadequate supply of plant food and water causes the gradual drying back and dying of the extremities of the branches, and in time the affected trees show staghead. Armillaria infection at the base of a large root quickly reduces the amount of food and water supplied by the root and causes dieback or death of the branches that are supported by the infected root. Infections of this type in several roots cause the relatively sudden death of the tree.

In the soil, rhizomorphs are dark reddish brown to hlack externally, cylindric,

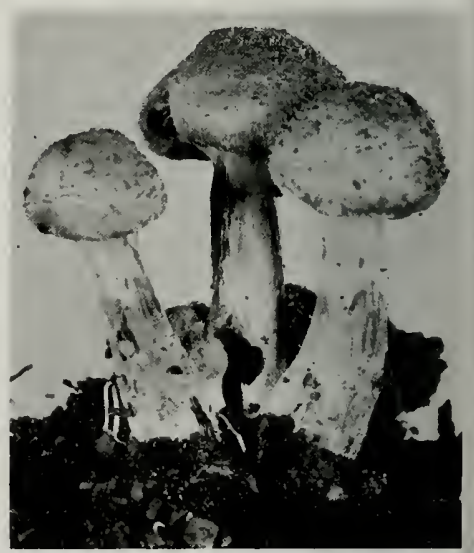

Fig. 39.- Sporophores of Armillaria. This group of sporophores developed at the hase of a dead bur oak root. $\mathrm{X} 3 / 4$. 
little branched, $0.5-3 \mathrm{~mm}$. in diameter, and they contain cream to white hyphal strands. The rhizomorphs that develop in the cambial region of the roots and tree trunks are dark red to reddish brown, Hattened, much branched, 0.2-3 nm. broad, and they contain cream to white hyphal strands.

Sporophores of Irmillaria develop, usually in October in Illinois, on the dead bark of the trunks and the roots of infected trees. Also they may be found on the ground at or near the base of the infected trees and sometimes at distances of several feet from them. A group of immature sporophores taken from the root of an oak may be seen in fig. 39 .

\section{MISCELLANEOUS FUNGI}

\section{Cylindrosporium}

Cyliudrosporium was found fruiting in the diseased tissue of one dieback specimen of shingle oak. The fungus was not grown in culture from this specimen nor from any other specimens of diseased oak. However, Coryue um was grown in culture from the diseased tissue of this specimen and was most likely the fungus responsible for the dieback. The Cylindrosporium evidently developed in the bark after the branch had become infected with Coryneum.

The diseased bark of this shingle oak specimen is light to dark hrown, slightly shrunken and for the most part smooth: however, where the numerous Cylindrosporium acervuli have been produced there

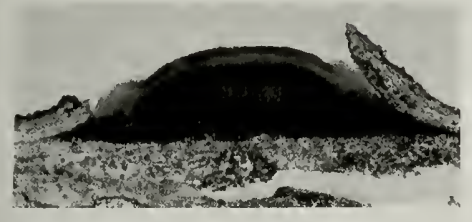

Fig. 40. Acervulus of Cylindrosporium on shingle oak. A vertical section of an acervulus which shows the position of the acervulus in relation to the host tissues. I 75 .

are hlisters. An acervulus is shown in vertical section in fig. 40 . Acervuli are dark hrown to black, pulvinate and immersed. They become erumpent at maturity and are $530-1100 \mu$ in diameter and $130-400$ $\mu$ high. The acervuli arise fundamentally in the phellogen-phelloderm region of the bark and at first cause very little distortion and disintegration of the cortical cells. As they expand in growth and become mature, they rupture the overlying phellem and epidermis, which form shields around

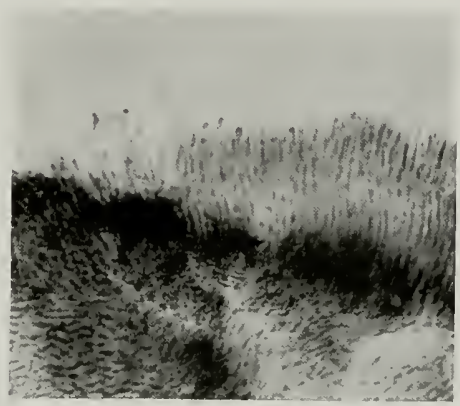

Fig. 41. - Spores of Cylindrosporimm :4 tached to a portion of an acervulus. The spores are hyaline, acicular and straight to curved. × 500 .

them. The conidia, shown in fig. +1 , are hyaline, $20-t 0 \times 1-3 \mu$, acicular, 1 - to 2-celled, and straight to curved.

This fungus does not appear to compare morphologically with any of the described species of Cylindrosporium that have been found on Quercus.

\section{Cylindrosporium quercinum sp. nov.}

Acervuli scattered, dark brown to black, pulvinate, innate, becoming erumpent, $530-1100 \mu$ in diameter, $130-400 \mu$ high, inhabiting an elongated, light to dark hrown diseased region of the branch; conidia hyaline, acicular, continuous to I-septate, straight or slightly curved, 20to $\times 1-3 \mu$.

Acervulis sparsis atrobrunneis usque nigris pulvinatis innatis dein crumpentibus $530-1100$ $\mu$ diametris $130-400 \mu$ altis regione m elongatam di)utam usque atratam hrunneam aegrotam rami incolentihus, conidiis hyalinis acicularihus continuis vel 1-septatis rectis curvulisve $20-40$ $\times 1-3 \mu$.

Type specimen: Collected by G. H. Boewe, Cartter, Marion County, Illinois, on branch of Quercus imbricaria Michx.. September 17, 1936, 111. Nat. Hist. Surv. Acc. No. 27,081 . 


\section{Rhodosticta}

Rhodosticta was found fruiting on a single specimen of dieback, taken from a pin oak growing in a nursery row. The diseased branch, approximately 1 inch in parenchymatous hyphae that compose the bases of the stromata. The overlying phellem and epidermis are ruptured and forced back to form a collar around the erumpent stromata.

Erumpent stromata are shown in fig. 42.

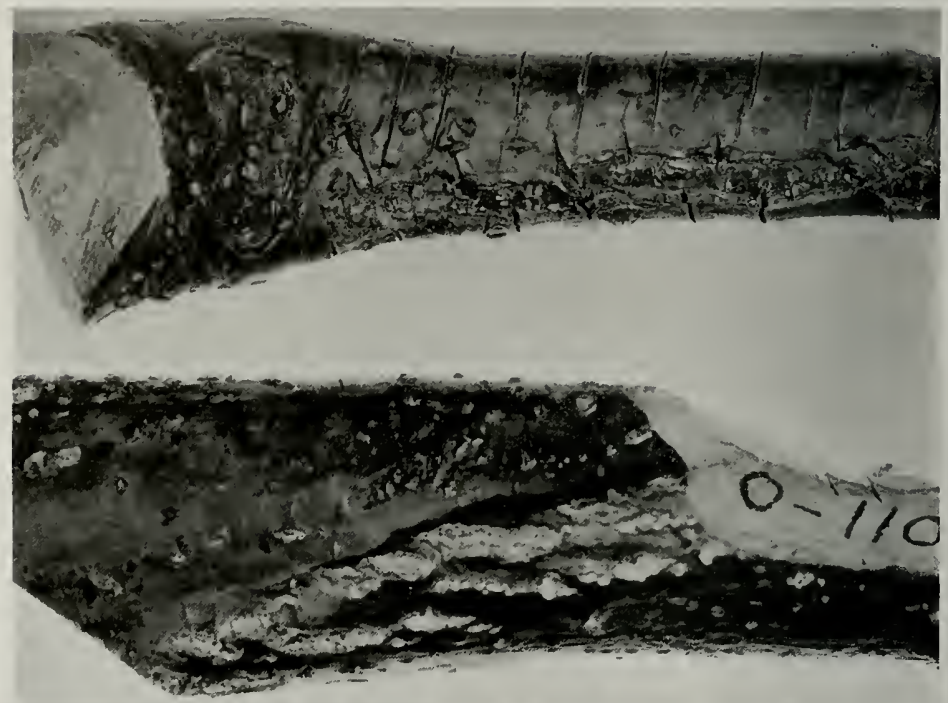

Fig. 42.- Dieback of pin oak with Rhodosticta fruiting in the diseased tissue. The central region of the shrunken and smooth diseased bark is pale yellow but it blends into a light brown and then into a dark brown at the border. The scattered, ovoid to irregular, red stromata are present in the discolored, diseased tissue. $\mathrm{X} 2$.

diameter, had become infected through the stub of a lateral.

The color of the diseased bark in the central region is white to pale yellow, blending into a light hrown and then into a dark brown toward the margin. A raised region of callus tissue contrasts sharply with the adjacent diseased bark. This contrast marks a definite separation of the living and dead tissues. Light brown discoloration of the dead wood beneath the diseased hark does not extend into the living wood.

Stromata are laid down fundamentally in the phellogen-phelloderm region of the branch. These tissues and the underlying cortex are partially disintegrated and crushed by the development of the pseudo-

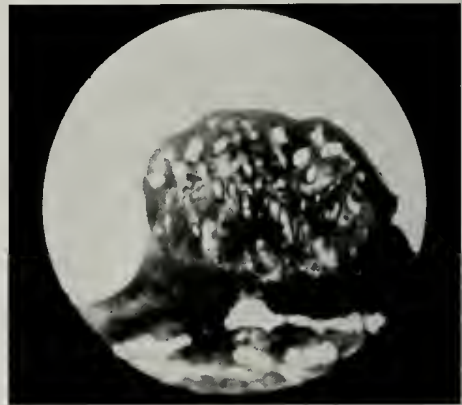

Fig. 43.--Stroma of Rhodosticta. A vertical section of a stroma which shows the variable shape and arrangement of the pycnidia. I 29. 
They are red, ovoid, with an irregular outer surface, not crustose, $1200-1500 \mu$ in diameter and $800-1000 \mu$ high. The pycnidial cavities, visible in the vertical section of the stroma, illustrated in fig. +3 , are ovoid to irregular, promiscuously dispersed throughout the stromatic tissue and variable in size. They are of three types: small, oval cavities, $60-65 \times 25-35 \mu$; large, oval cavities, $160-180 \times 30-40$

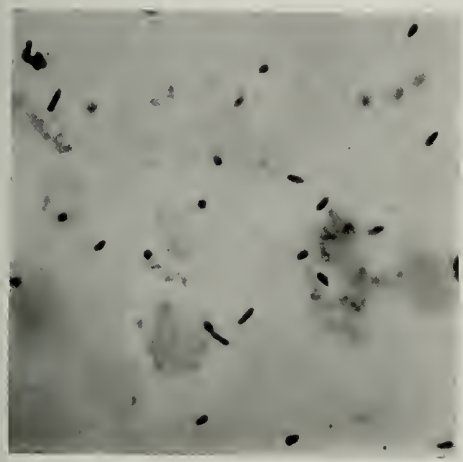

Fig. 44. - Spores of Rhodosticta. The spores are minute, ovoid to ellipsoid, and byaline to subhyaline. I 860 .

$\mu$; and long, narrow cavities, 115-135 $\times$ $70-85 \mu$. The conidia, shown in fig. +4 , are hyaline to subhyaline, $2.8-3.5 \times 1-2$ $\mu$, and ovoid to ellipsoid. The fungus was not grown in culture.

Our material does not compare with Rhodosticta Caragamae IVoronichin (Saccardo 1913). The present report is believed to be the first of Rhodosticta on Ouercus.

\section{Rhodosticta quercina sp. nov.}

Stromata scattered, red, tubercular, not crustose, $1200-1500 \mu$ in diameter, $800-$ $1000 \mu$ high, inhabiting a light to dark brown diseased region of the branch; pycnidia ovoid to irregular, immersed, 60 $180 \times 25-85 \mu$; conidia hyaline to subhyaline, ovoid to ellipsoid, $2.8-3.5 \times$ 1-2 $\mu$.

Stromatibus sparsis rubris tuberculiformibus non crustosis $1200-1500 \mu$ diametris $800-1000 \mu$ altis regionem dilutam usque attratam brunneam aegrotam rami incolentibus, picnidiis ovoideis usque irregularibus immersis $60-180 \times 25-85 \mu$, conidiis hyalinis usque subhyalinis ovoideis usque ellpisoideis 2.8-3.5 $\times 1-2 \mu$

Type specimen: Collected by J. C. Carter, Onarga, Iroquois County, Illinois, October 25, 1935, on branch of Quercus palustris Muench., 111. Nat. Hist. Surv. Acc. No. 27,083.

\section{Cephalosporium}

Cephalosporium was obtained in culture from 27 specimens of diseased oaks, black, red, shingle and white. It was isolated from cankerous wood and bark and from discolored living wood of red, shingle and white oaks, and from a living twig of black oak that had blighted leaves. Cephalosporium was the only fungus isolated from the living wood below cankers of three specimens of red oak and of one specimen of white oak. In each case th fungus was isolated from discolored, light to dark brown living wood that was taken at points 1 to 3 inches below the cankers. Cephalosporium was obtained from most specimens in association with other fungi, including Alternaria, Coniothyrium, $C o$ ryneum, Cytospora, Penicillium, Pestalotin. Phoma and Dothiorella. The onls cultures of Cephalosporium not associated with other fungi were obtained from discolored dead wood and, as pointed out above, from discolored living wood.

On corn meal agar the surface of old cultures of this Cephalosporium appears granular or pulverulent. The appearance is due to the numerous conidia produced. The fungus grows and spreads rapidly over the surface of the agar. Conidiophores, produced on septate, hyaline, hranched hyphae, are unbranched, variable in length but approximately $250-300 \times$ $2-3 \mu$, hyaline and filiform. Conidia are capitate, hyaline, ellipsoid to ovoid, sessile, $2-3 \times 1.5-2 \mu$ to $7.5-10 \times 3-3.5 \mu$, most frequently $3-t \times 1.5-2 \mu$, and produced acrogenously in globose heads on the conidiophores.

\section{Nigrospora}

Nigrospora was isolated from two specimens of diseased oak: one isolate from a blighted twig of post oak and one from a blighted petiole of pin oak. The blighted 
twig was hrown internally and had blighted leaves with purplish petioles attached. The blighted petiole was shriveled, dead purplish internally and externally, and was attached to a twig that had hyper-

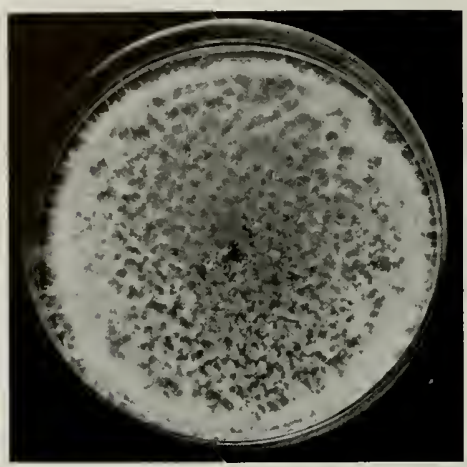

Fig. 45.- Culture of Nigrospora. The white to gray, abundant growth of mycelium develops on corn meal agar.

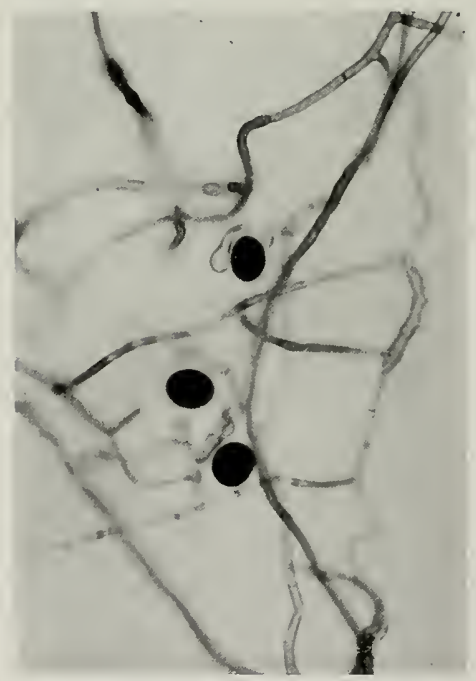

Fig. 46. Spores of Nigrospora. The black, smooth, globose to ovoid spores develop singly on doliform basidia. $\mathrm{X} 320$. trophied buds. Nigrospora was not found fruiting on the diseased wood of any specimens of oak, Both Nigrospora and Cory'neum were cultured from the hlighted twig of post oak; Dothiorella and Alternaria, as well as Nigrospora, were cultured from the blighted petioles of pin oak.

When grown on corn meal agar, the Nigrospora discussed here develops a dense surface and aerial growth of hyphae that is white and somewhat powdery. A culture is illustrated in fig. +5 . Produced on erect conidiophores, the black, exogenous, smooth, globose to ovoid, acrogenous conidia, shown in fig. 46 , develop singly on doliform basidia and are 11.5-22 $\mu$, most of them approximating $15.5 \mu$, in diameter. Sometimes the conidiophores are branched, and several conidia develop on each of the branched conidiophores.

This Nigrospora agrees with Nigrospora sphaerica (Sacc.) Mason on elm, discussed by Harris (1932). Harris' material was determined by E. W. Mason of the Imperial Mycological Institute.

\section{Cunninghamella}

Cunninghamella was isolated from a specimen of red oak dieback. The dieback had developed where the branch was broken. The diseased bark was reddish hrown, shrunken and cracked crosswise. The xylem tissue under the bark was discolored dark brown to black with fine streaks that extended into the living xylem below the base of the dieback region. Immature fungous fruit bodies were present in the diseased bark. The fungus was cbtained in culture not only from dead discolored wood but from living discolored wood taken from an area approximately 1 inch below the base of the dieback region.

This Cunninghamella develops a sparse growth of yellowish-tan surface mycelium on corn meal agar. Conidia are borne in abundance on erect, tan conidiophores. Sporangia and sporangioles are lacking. The condiophores, shown in fig. 47 , are continuous with the hyphae and are tan, straight or curved, $75-300 \times 4-6 \mu$, frequently joined to the hyphae at right angles and apically swollen. The swollen apices of the conidiophores are 9-15 $\mu$ in diameter. Conidia, shown in fig. 47 , are globose, $2.9-3.3 \mu$ in diameter, $\tan$ and 


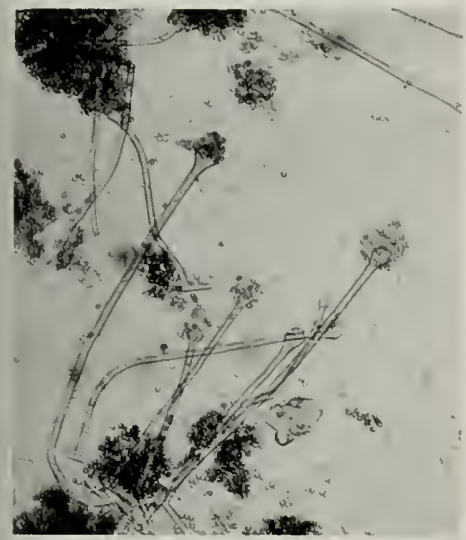

Fig. 47.-Spores and conidiophores of CuHninghamella. The glohose, tan, echinulate spores are produced on erect, tan, apically swollen conidiophores. X 200.

echinulate. The hyphae are coenocytic, hyaline and $2.8-3.5 \mu$ in diameter.

This is believed to be the first report of a Cunninghamella cultured from diseased oak wood; no attempt has been made to secure zygospore production, and the species has not been determined.

\section{Pestalotia}

Pestalotia was isolated from living tissue of a black oak twig that had blighted leaves attached to it. The twig was not discolored internally, but the leaves were dead and brown, and the petioles were purplish, shriveled and dead. No fungus was fruiting on the twig or on the attached petioles. Cephalosporium and Dothiorella as well as Pestalotia were obtained in culture from the twig.

This Pestalotia produces a sparse growth of light to dark tan surface and aerial mycelium on corn meal agar. Scattered acervuli are dark brown to black, ovoid to globoid and $300-400 \mu$ in diameter. The conidia, shown in fig. 48 , are clavate. mostly straight, 5-celled, not constricted to slightly constricted at septa, 20-30 X $6-9 \mu$, and with setae (usually $f$ ) on each apical cell. Basal cells of the conidia are hyaline and ellipsoid to conoid. Apical cells ate hyaline and somewhat conoid. The intermediate cells, 3 in each conidium, are hrown: the upper 2 dark hrown and

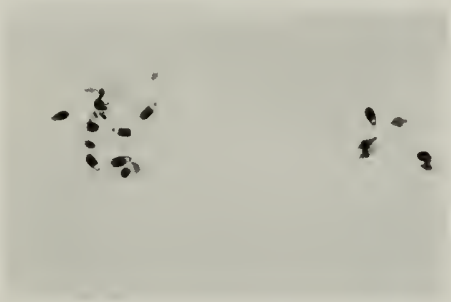

Fig. 48.- Spores of Pestalotia. The clavate, 5-celled spores have hvaline apical and basal cells, and brown intermediate cells. There are usually 4 setae on the apical cell of each spore. $\therefore 200$.

t.'e lower 1 light brown to tan. The setae are $25-40 \times 2.8-3 .+\mu$ and hyaline. The basidia are 9-12 $\times 1-2 \mu$ and hyaline.

This fungus was determined as Pestalotia clazispora Atk. (Atkinson 1897). The determination was verified by Dr. E. F. Guba.

\section{Chaetomium}

A single isolation of Chae tomium, a culture of which is shown in fig. 49 , was secured from brownish-hlack, discolored live wood of white oak. The discolored live

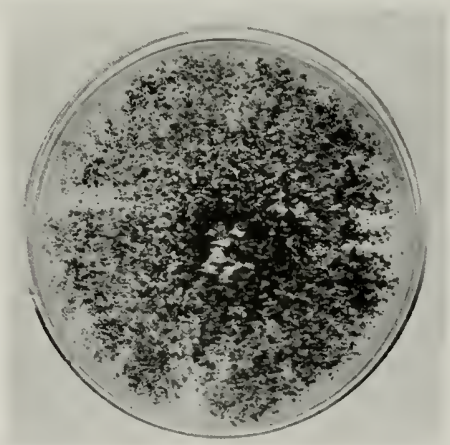

Fig. 49. Culture of Chaelomium. Numerous hrownish-black, ovoid, membranous perithecia develop on corn meal agar. 
wood was adjacent to the base of a diseased region that showed dieback. Both Chatomium and Cytospora were obtained from this specimen of dieback. The living wood from which Chaetomium was isolated showed black, discolored streaks that appeared to be identical with the black streaks that are commonly associated with Dothiorella infection of oak, as illustrated in fig. 3 .

The Chaetomium discussed here produces appendaged brownish-black, ovoid, membranous perithecia in abundance on corn meal agar. The perithecia are 375$+25 \mu$ in diameter and $270-300 \mu$ high. Appendages are dark brown to black, long wavy to spiral (wavy at base and spiral toward top of perithecia) and, above the perithecia, form dense tufts that measure $610-650 \mu$ in diameter and $400-+15 \mu$ high. The asci are hyaline, ovoid to clavate, 8 -spored, $40-50 \times 12-1+\mu$, and tapering to $6-7 \mu$ in diameter near the base. Ascospores are olivaceous, 9.3-11 $\times 7-9 \mu$, and lemon shaped.

This Chaetomium was identified as Chaetomium globosum Kunze by Dr. J. A. Stevenson.

\section{Alternaria}

Alternaria was frequently obtained in culture from diseased bark and wood and occasionally from blighted petioles of black, bur, chinquapin, pin, post, red, shingle, swamp white and white oaks. Only one isolation of Alternaria was obtained from the living wood of a specimen of diseased oak-white oak. This specimen showed fine streaks of black discoloration that extended from a canker into the living wood a few inches up the branch. Large, black, carbonous and immature stromata, characteristic of the stromata of Nummularia, were present in the diseased tissue.

The Alternaria isolated from oak is similar to the Alternaria that is frequently obtained from diseased woody tissues of other hosts. A culture of the Alternaria from oak, grown on corn meal agar, is shown in fig. 50 . The dense growth of surface and aerial mycelium is dark brown to almost black, and conidia are produced in abundance. The conidia are dark brown to almost black, $9-46 \times 6-12 \mu$, averaging approximately $21 \times 9 \mu$, muriform,

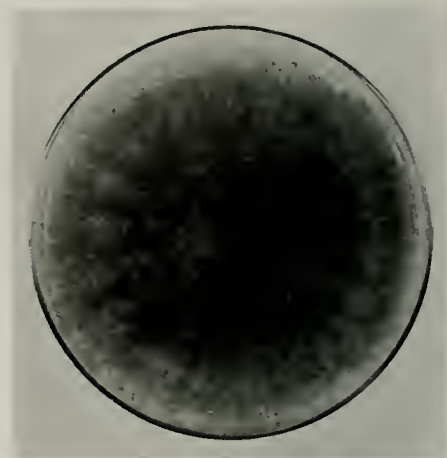

Fig. 50.-Culture of Alternaria. This fungus produces a dark brown myceliun that grows rapidly over the surface of corn meal agar.

catenulate, with 1 to 6 , usually 3 to 4 , transverse septa, and with none to 3 , usually 1 to 3 , longitudinal septa.

\section{Penicillium}

Penicillium, fig. 51, was obtained in culture from specimens of diseased living and dead wood of oak, including red, white and an unidentified species. It was obtained from living wood that showed dark brown to black, discolored streaks and from dead wood at the junction of the

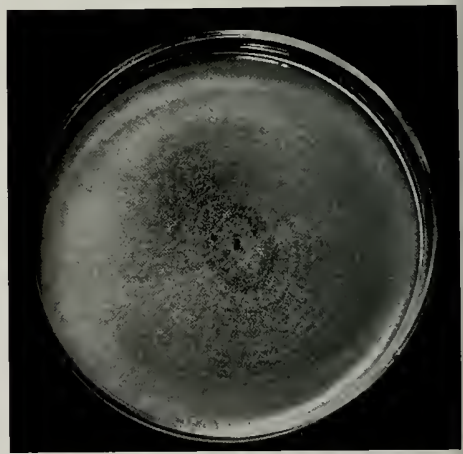

Fig. 51.- Culture of Penicillitum. The gray to pale green mycelium develops on corn meal agar. Abundant production of spores causes the mycelium to have a granular surface appearance. 
living and dead wood of a single dieback specimen of red oak. Scattered, black, erumpent stromata of Cytospora were present in the diseased bark of this particular specimen of dieback. The diseased bark was dark brown and was shrunken and attached closely to the underlying brown to black, discolored wood. Penicillium, Cephalosporium and an unidentified fungus were obtained from a second specimen of diseased red oak. Both Penicillium and Dothiorella were obtained from a specimen of diseased white oak: Phoma and bacteria, as well as Penicillium. from the diseased wood of the unidentified species of oak.

The conidia of Penicillium are hyaline, t.t $+.8 \times 3.4-3.8 \mu$, oroid to globose. and catenulate. The light green mycelium develops as concentric circles of sparse and dense growth that spreads rapidly on corn meal agar.

\section{SUMMARY}

In this investigation it was found that in Illinois diseases of oak, namely, cankers, dieback, twig blight and root rot, are important in the decline and death of trees in nursery, shade and ornamental plantings and in native stands. Numerous fungi, of which 22 are described in this paper. were associated with cankers, deep wood infections, dieback and twig blight. Some of the fungi associated with cankers frequently were found fruiting on or were isolated from specimens of dieback and twig blight. It was apparent, in many cases, that canker infections developed into dieback when the infected branches were completely girdled by the invading fungus.

The fungi associated most consistently with canker and dieback of oak were species of Dothiorella, Coryncum, Cytospora, Nummularia, Diatrype and Phomopsis. Those associated principally with canker diseases were species of Phoma, Fusicoccum, Sphaeropsis and Bulgaria. Those associated mainly with dieback diseases were species of Coniothyrium and Pyrenochaeta. Dothiorella quercina (Cke. \& Ell.) Sacc. and Coryneum Kunzei Corda were the fungi associated most frequently. with the diseases of oak. The fungi described in this paper can develop on dead oak wood as saprophytes. Many of them are potential parasites of oak trees, especially when the trees are growing under adverse conditions.

This investigation was made on diseased material of black, black jack, bur, chinquapin. Hill's, pin, post, red, shingle. swamp white and white oak.

Inoculation trials were made with Dothiorella quercina and with Coryneum Kunzei. Black, red and white oaks inoculated with $D$. quercina became infected and showed canker and dieback symptoms tupical of those described as characteristic of Dothiorella canker and dieback. $D$. quercina was reisolated in pure culture from the inoculated oaks.

Two of the three white oaks inoculated with Coryneum Kunzei died within 1 month after ther were inoculated; however, C. Kunzei was not reisolated from either of these two oaks. The third white oak inoculated with $C$. Kunzei showed no symptoms of infection at the end of 21 months.

\section{LITERATURE CITED}

Anderson, H. W.

1922. Notes of new diseases of economic crops in Illinois, 1919-1921. III. Acad. Sci. Trans. 15:130-40.

\section{Anonymous}

1930. State of New York. Conservation Dept., Ann. Rep. to Legislature 1930:202-3.

1931. State of New York. Conservation Dept., Ann. Rep. to Legislature 1931:168.

1934. State of New York. Conservation Dept., Ann. Rep, to Legislature $1934: 33 t-5$.
Ashcroft, J. M.

1934. Furopean canker of black walnut and other trees. IV. Va. Ag. Fxp. Sta. Bul. 261.

Atkinson, G. F.

1897. Some fungi from Alabama. Cornell U'niv. Bul. 3:1-50.

Babcock, D. C.

1915. A new scarlet oak disease. Phytopatn. $5: 19 \%$.

1916. Diseases of forest and shade trees. Ohio Ag. Exp. Sta, Monthly Bul. $1: 33 i-8$. 


\section{Bavendamm, W.}

1936. Dolhidia noxia on American oak (trans. title). Tharandter Forstl. Jahrh. 86(4-5):273-5. 1935. [Exp. Sta. Rec. 74:805.]

Bidwell, C. B., and IV. C. Bramble

1934. The Strumella disease in southern Connecticut. Jour. Forestry 32: 15-23.

Boyce, J. S.

1938. Forest pathology, pp. 110-5, 284, 287, 310. McGraw-Hill Book Company, 1nc., New York.

Braid, K. W.

1924. Some observations on Fistulina hepatica and hollow, stag-headed oaks. Brit. Mycol. Soc. Trans. 9: 210-3.

Bramble, W. C.

1934. Occurrence of the Strumella disease in the Midwest. Jour. Forestry 32: 614 .

Brooks, F. T.

1928. Plant diseases, p. 204. Oxford Univ. Press. Humphrey Milford, London.

\section{Brown, Nellie A.}

1938. The tumor disease of oak and hickory trees. Phytopath. 28:401-11.

Buckhout, W. A.

1900. The undesirability of red and black oaks because of fungus diseases. Pa. Ag. Exp. Sta. Ann. Rep. 1899: 250-2.

Campbell, A. H.

1934. Zone lines in plant tissues 11. The black lines formed by Armillaria mellea (Vahl.) Quél. Ann. Appl. Biol. 21:1-22.

Carter, J. C.

1936. Cytosporina ludibunda on American elm. Phytopath. 26:805-6.

1938. Fungi associated with oak diseases. Phytopath. 28:4-5. [Abst.]

1940. Diseases of oaks and Verticillium wilt of woody plants. Natl. Shade Tree Conf. Proc. 16:83 91.

\section{Cartwright, K. St. G.}

1929 A statisfactory method of staining fungal mycelium in wood sections. Ann. Bot. 43:412-3.

1937. A reinvestigation into the cause of "brown oak," Fistulina hepalica (Huds.) Fr. Brit. Mycol. Soc. Trans. $21: 68-83$.

\section{Clinton, G. P.}

1934. Plant pest handbook for Connect;cut 11. Diseases and injuries. Conn. Ag. Exp. Sta. Bul. 358:1-329.

Cooke, M. C., and H. W. Harkness

1884. California fungi. Grevillea 13:111-4.
Craighead, F. C.

1923. North American cerambycid larvae: Canada Dept. Ag. Bul. 27:90. (New scries, technical.)

Crandall, B. S., Carl Hartley and R. W. Davidson

1937. Wetwood. Phytopath. 27:126. [Abst.]

Davidson, Ross W.

1935. Forest pathology notes. U. S. Dept. Ag., Pl. Dis. Rep. 19:94-7.

Davis, W. H.

1935. A plant disease survey of trees and shrubs in western Massachusetts. U. S. Dept. Ag., Pl. Dis. Rep. 19: 260-9.

Edson, H. A., and Jessie I. Wood

1936. Diseases of plants in the United States in 1935. U. S. Dept. Ag., PI. Dis. Rep. Sup. 96:115-289.

Felt, E. P., and W. H. Rankin

1932. Insects and diseases of ornamental trees and shrubs, pp. 256-7, 261, 262. The Macmillan Company, New York.

Grant, Theodore J., and Perley Spaulding

1939. Avenues of entrance for cankerforming Nectrias of New England hardwoods. Phytopath. 29:351-8.

Groom, P.

1915. Brown oak and its origin. Ann. Bot. 29:393-408.

Guba, E. F.

1934. Slime flux. Natl. Shade Tree Conf. Proc. 10:56-60

Haensler, C. M.

1932. Twig blight and canker of the chestnut oak. N. J. Ag. Exp. Sta. Dept. Bot. Nursery Dis. Notes 4(12):3-4.

\section{Harris, Hubert A.}

1932. Initial studies of American elm diseases in Illinois. Ill. Nat. Hist. Surv. Bul. 20(1):1-70.

Hartley, C., and B. S. Crandall

1935. Vascular disease in poplar and willow. Phytopath. 25:18-9. [Abst.]

\section{Hartig, $\mathbf{R}$.}

1894. The diseases of trees (translated by William Somerville and H. Marshall Ward), pp. 90-6, 99-102, 206-7. Macmillan and Company, London.

Heald, F. D.

1914. A little-known disease of chestnut and oak trees. Phyt opath. 4:49. [Abst.]

1937. Introduction to plant pathology, pp. 227-34. McGraw-Hill Book Company, Inc., New York. 
Heald, F. D., and R. A. Studhalter

1914. The Strumella disease of oak and chestnut trees. Pa. Dept. Forestry Bul. 10:1-15.

\section{Hennings, $P$.}

1894. Ueber das Vorkommen von Bulgarin polymorpha Oeder an lebenden Fichen. Ztschr. f. Pflanzenkrank, 4:266.

\section{Henry, E.}

1902. Note sur quelques nouveaux champignons parasites de chènès. Soc. Bot, de France Bul. 49:151-5.

Holtz, W.

1901. Beitrag zur Kenntnis der Baumflüsse und einiger ihrer Bewohner. Centbl. i. Bakt. [etc.], Abt. 11, 7: $113-28, \quad 179-89, \quad 229-38,274-81$, 338-50.

\section{Horne, W. T.}

1914. The oak fungus disease of fruit trees. Calif. Comm. Hort. Monthly Bul. 3:275-8?

1915. Oak fungus on Armillaria mellea in connection with nursery stock. Calif. Comm. Hort. Monthly Bul. 4:17983.

1919. Oak fungus disease, oak-root fungus disease, fungus root rot, toad-stool root rot or mushroom root rot. Calif. Comm. Hort. Monthly Bul. $8: 64-8$.

\section{Hubert, E. E.}

1931. An outline of forest pathology, pp. 417-22. John Wiley and Sons, Jew Iork.

Humphrey, H. B., and J. I. Wood

1935. Diseases of plants in the United States in 1933. [U. S. Dept. Ag., Pl. Dis. Rep. Sup. 86:107.

\section{Ingram, Della $\mathrm{E}$.}

1912. Preliminary notes on a twig blight of Quercus Prinus. Phytopath. 2:96. [Abst.]

1914. A twig blight of Quercus Prinus and related species. Jour. Ag. Res. 1:339-46.

Kendall, T. A.

1931. Soil aeration used in treatment for oak-root fungus. Calif. Dept. Ag. Monthly Bul. 20:165-6.

Kienholz, R., and C. B. Bidwell

1938. A survey of diseases and defects in Connecticut forests. Conn. INew Haven] Ag. Fxp. Sta. Bul. 412:489559.

Lefebvre, C. L., and C. O. Johnston

193.5. Kansas mycological notes, 1934. Kan. Acad. Sci. Trans. 38:101-3.

Ludwig, F.

1886. Leber Alkoholgährung und Schleim- fluss lebender Bäume. Hedwigia 25: $168-72$.

1887. 1st Bulgaria inquinans ein Wund Parasit? Centbl. f. Bakt, u. Parasitenkunde 2:521.

1888. Der braune Schleimfluss. Centbl. f Bakt. u. Parasitenkunde 4:32.3 4 .

Massee, George

1907. New and additional species of fungi. Second series. Kew Bul. 238-44.

1910. Diseases of cultivated plants and trees, pp. 183, 210, 250. Duckworth and Company, London.

\section{McKenzie, Malcolm A.}

1937. Tree diseases in Massachusetts. U. S. Dept. Ag., Pl. Dis. Rep. 21 $55-8$

\section{Moreillon, M.}

1918. Diaporshe taleola, an ascomycete injurious to oaks. [Abst, in 1nternatl. Inst. Ag. (Rome), Internat. Res. Sci. and Pract. Ag. 9, 3,397-8,

\section{Newman, $R$.}

1926. Oak fungus situation. Pacific Rural Press 111:6.

Ogilvie, L.

1924. Ohservations on the "slime fluxes" of trees. Brit. Vivcol. Soc. Trans. 9:16 $\mathbf{\imath}-\$ 2$.

Orton, W. A.

1908. Plant diseases in the Lnited States in 1907 . [. S. Dept. Ag. Yrbk. 1907 577

Overholts, L. O.

1934 Mycological notes for 1033. Nycologia 26:506.

Owens, C. E.

1928. Principles of plant pathology, pp. 446-52. John Wiley and Sons, Tew York.

Rankin, W. H.

1914. Sphacropsis canker of Quercus Primus. Phytopath, 4:4t-5. [Abst.]

192i. Manual of tree diseases, $p p$. is 8 ? 244-6. The Macmillan Company, New York.

Ruhland, W.

1904. Ein neuer, verderblicher Schädling der Eiche. Centbl. t. Bakt. letc.], Abt. 11, 12:250-3.

Saccardo, P. A.

1884. Sylloge fungorum omnium hucusque cognitorum. Patavii, sumptibus auctoris. $\mathbf{3}: 96,240,248$.

1592. Silloge fungorum omnium hucusque cognitorum. Patavii, sumptihus auctoris. 10:161.

1899 Sylloge fungorum omnium hucus- 
que cognitorum. Patavii, sumptibus auctoris. 14:913, 924 .

1913. Sylloge fungorum omnium hucusque cognitorum. Patavii, sumptibus auctoris. $22: 1142$.

Sieeth, B., and C. B. Bidwell

1937. Polyporus hispidus and a canker of oaks. Jour. Forestry 35:778-85.

Spaulding, P., T. J. Grant and T. T. Ayers

1936. Investigations of Nectria diseases in hardwoods of New England. Jour. Forestry 34:169-79.

\section{Taubenhaus, J. J.}

1934. Live oak disease at Austin. Tex. Ag. Exp. Sta. Ann. Rep. 1934:97-8.

1935. Live oak disease at Austin. Tex. Ag. Exp. Sta. Ann. Rep. 1935: $99-100$.

Taubenhaus, J. J., and W. N. Ezekiel

1932. City tree diseases at Fort Worth. Tex. Ag. Exp. Sta. Ann. Rep. 1932: 76.

Tehon, L. R., and WV. R. Jacks

1933. Smooth patch, a bark lesion of white oak. Jour. Forestry 31:430-3.

\section{Thomas, Harold E.}

1934. Studies on Armillaria mellea (Vahl.) Quél. infection, parasitism and host resistance. Jour. Ag. Res. 48:187218.

Tubeuf, K. von, and W. G. Smith

1897. Diseases of plants induced by cryptogamic parasites, pp. 142, 144.
Longmans, Green and Company,
New York.

Ward, H. Marshall

1901. Diseases in plants, p. 233. Macmillan and Company, London.

\section{Waterman, Alma $\mathbf{M}$.}

1939. Diseases of shade and ornamental trees. U. S. Dept. Ag., Pl. Dis. Rep. 23:85-7.

Wehmeyer, L. E.

1926. Cultural life histories of Melanconis and Pseudovalsa. Mycologia 18: 257-73.

Weir, J. R.

1925. Notes on the parasitism of Endothia gyrosa (Schw.) Fr. Phytopath, 15: 489-91.

Welch, D. S.

1934a. Nectria canker on hardwoods in northeastern United States. U. S. Dept. Ag., Pl. Dis. Rep. 18:21-2.

1934b. The range and importance of Nectria canker on hardwoods in the Northwest. Jour. Forestry 32:9971,002 .

White, R. P.

1936. Notes on new or unusual outbreaks of diseases of ornamentals in New Jersey in 1935. U. S. Dept. Ag., Pl. Dis. Rep. 20:79-81.

Zeller, S. M., and C. E. Owens

1922. European canker in Pacific Coast states. Phytopath. 12:105. 